\title{
Long term measurements of aerosol optical properties at a primary forest site in Amazonia
}

\author{
L. V. Rizzo ${ }^{1}$, P. Artaxo ${ }^{2}$, T. Müller ${ }^{3}$, A. Wiedensohler ${ }^{3}$, M. Paixão ${ }^{3}$, G. G. Cirino ${ }^{4}$, A. Arana ${ }^{2}$, E. Swietlicki ${ }^{5}$,

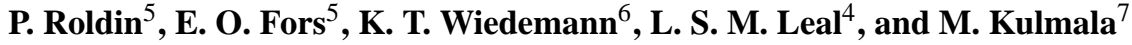 \\ ${ }^{1}$ Department of Earth and Exact Sciences, Institute of Environmental, Chemical and Pharmaceutics Sciences, Federal \\ University of São Paulo, Sao Paulo, Brazil \\ ${ }^{2}$ Department of Applied Physics, Institute of Physics, University of São Paulo, Sao Paulo, Brazil \\ ${ }^{3}$ Leibniz Institute for Tropospheric Research, Leipzig, Germany \\ ${ }^{4}$ National Institute for Amazonian Research (INPA), Manaus, Brazil \\ ${ }^{5}$ Division of Nuclear Physics, Physics Institute, Lund University, Lund, Sweden \\ ${ }^{6}$ Division of Engineering and Applied Science/Department of Earth and Planetary Science, Harvard University, \\ Cambridge, USA \\ ${ }^{7}$ Department of Physical Sciences, Division of Atmospheric Sciences, University of Helsinki, Helsinki, Finland
}

Correspondence to: L. V. Rizzo (lrizzo@unifesp.br)

Received: 28 August 2012 - Published in Atmos. Chem. Phys. Discuss.: 10 September 2012

Revised: 14 February 2013 - Accepted: 18 February 2013 - Published: 1 March 2013

\begin{abstract}
A long term experiment was conducted in a primary forest area in Amazonia, with continuous in-situ measurements of aerosol optical properties between February 2008 and April 2011, comprising, to our knowledge, the longest database ever in the Amazon Basin. Two major classes of aerosol particles, with significantly different optical properties were identified: coarse mode predominant biogenic aerosols in the wet season (January-June), naturally released by the forest metabolism, and fine mode dominated biomass burning aerosols in the dry season (July-December), transported from regional fires. Dry particle median scattering coefficients at the wavelength of $550 \mathrm{~nm}$ increased from $6.3 \mathrm{Mm}^{-1}$ to $22 \mathrm{Mm}^{-1}$, whereas absorption at $637 \mathrm{~nm}$ increased from $0.5 \mathrm{Mm}^{-1}$ to $2.8 \mathrm{Mm}^{-1}$ from wet to dry season. Most of the scattering in the dry season was attributed to the predominance of fine mode $\left(\mathrm{PM}_{2}\right)$ particles $(40-80 \%$ of $\mathrm{PM}_{10}$ mass), while the enhanced absorption coefficients are attributed to the presence of light absorbing aerosols from biomass burning. As both scattering and absorption increased in the dry season, the single scattering albedo (SSA) did not show a significant seasonal variability, in average $0.86 \pm 0.08$ at $637 \mathrm{~nm}$ for dry aerosols. Measured particle optical properties were used to estimate the aerosol forcing efficiency at the top of the atmosphere. Results indicate that in this pri-
\end{abstract}

mary forest site the radiative balance was dominated by the cloud cover, particularly in the wet season. Due to the high cloud fractions, the aerosol forcing efficiency absolute values were below $-3.5 \mathrm{~W} \mathrm{~m}^{-2}$ in $70 \%$ of the wet season days and in $46 \%$ of the dry season days. Besides the seasonal variation, the influence of out-of-Basin aerosol sources was observed occasionally. Periods of influence of the Manaus urban plume were detected, characterized by a consistent increase on particle scattering (factor 2.5) and absorption coefficients (factor 5). Episodes of biomass burning and mineral dust particles advected from Africa were observed between January and April, characterized by enhanced concentrations of crustal elements $(\mathrm{Al}, \mathrm{Si}, \mathrm{Ti}, \mathrm{Fe})$ and potassium in the fine mode. During these episodes, median particle absorption coefficients increased by a factor of 2, whereas median SSA values decreased by $7 \%$, in comparison to wet season conditions.

\section{Introduction}

The Amazon Basin constitutes a unique place for studying the impact of anthropogenic activities over natural atmospheric conditions. Under pristine circumstances, 
Amazonian aerosol particles come mostly from biogenic sources, with mass concentrations in the order of $10 \mu \mathrm{g} \mathrm{m}^{-3}$ and number concentrations ranging between 300 and $500 \mathrm{~cm}^{-3}$ (Martin et al., 2010a). This concentration range is among the lowest found on any continental site, and is similar to observations over remote oceans (Andreae, 2009). For example, observations in a remote continental site in Pallas, Finland, found aerosol concentrations of $410 \mathrm{~cm}^{-3}$ in average (Komppula et al., 2005); observations taken over the Indian Ocean report $361 \mathrm{~cm}^{-3}$ in average (Hudson and Yum, 2002). Since the mid 20th century, the Amazon Basin has been going through changes due to the expansion of agriculture, logging and urban areas (Davidson et al., 2012). As a consequence of these changes, a large amount of aerosols and trace gases have been added to the natural biogenic emissions, with impacts on the radiative budget in regional and global scale (Koren et al., 2004; Procopio et al., 2004; Sena et al., 2013).

In the last $20 \mathrm{yr}$, Amazonian aerosol particles have been the subject of a number of intensive studies, aiming for its characterization at primary forest sites (Martin et al., 2010b; Zhou et al., 2002; Artaxo and Hansson, 1995) and at disturbed areas (Kaufman et al., 1998; Artaxo et al., 2002; Andreae et al., 2004). In-situ long-term observations in Amazonia have been conducted only for aerosol particle mass and its elemental composition (Artaxo et al., 1994).

To fill the gap of continuous aerosol monitoring in Amazonia and its interactions with climate, a forest reserve north of Manaus city, in Brazil, was chosen as one of the four EUCAARI (European Integrated Project on Aerosol Cloud Climate and Air Quality interactions, Kulmala et al., 2011) measurement sites in developing countries. Under the framework of the EUCAARI project, measurements of aerosol physical and chemical properties were conducted between 2008 and 2009. Afterwards, it became a permanent measurement station in Amazonia, being maintained since 2010 under the scope of the AEROCLIMA project (Direct and indirect effects of aerosols on climate in Amazônia and Pantanal). The establishment of this permanent monitoring site provided, to our knowledge, the longest time series of in situ aerosol observations in Amazonia, using state of art equipment. This paper focuses on aerosol optical properties observed between 2008 and 2011.

The relevance of optical properties resides in the fact that aerosol particles interact with solar radiation with impacts on the regional radiation budget, climate and cloud properties (Hansen et al., 1997; Fan et al., 2008; Shindell and Faluvegi, 2009). The fourth IPCC assessment report (Forster et al., 2007) attributes a wide range of uncertainty to the aerosol forcing on climate, with implications to climate model projections related to uncertainties in model parameters (Haerter et al., 2009). Loeb and $\mathrm{Su}$ (2010) stated that the direct aerosol radiative forcing uncertainty due to perturbations on aerosol particles' physical parameters is $0.5-1.0 \mathrm{Wm}^{-2}$, with most of the uncertainty associated with aerosol single scattering albedo (SSA). Therefore, it is important to characterize accurately the optical properties of representative types of ambient aerosol particles to assess its impact on the Earth's energy budget and climate change.

The aim of this paper is to present a systematic analysis of aerosol particle optical properties in a primary forest site, its annual variability, seasonality and relationships with aerosol particle mass, number concentration and particle number size distribution. As will be discussed along the paper, in spite of the fact that the measurement site is located in a primary forest area, it is occasionally influenced by external aerosol sources like regional biomass burning, urban plumes and African mineral dust advection. The impact of these out-of-Basin sources over the optical properties of natural aerosol population will be investigated, as well as the consequences over the aerosol forcing efficiency.

\section{Experimental}

\subsection{Measurement site}

Measurement of aerosol particle properties were taken from February 2008 to February 2011 at the Cuieiras forest reservation in Central Amazonia (Fig. 1), which encloses $380 \mathrm{~km}^{2}$ of tropical forest. The reserve is located $60 \mathrm{~km} \mathrm{NNW}$ of Manaus, a developing city with a population of 1.8 million people (IBGE, 2011). The site is relatively undisturbed, in the sense that no biomass burning occurs in the reservation. Most of the time, the prevailing trade winds blow over vast expanses of intact tropical forest before reaching the measurement tower (TT34) $\left(2^{\circ} 35.6570^{\circ} \mathrm{S}, 60^{\circ} 12.5570^{\circ} \mathrm{W}, 110 \mathrm{~m}\right.$ a.s.l. $)$. However, as will be further discussed, the site was affected by regional transport of pollutants, either from biomass burning or urban plumes.

All measurements were taken under dry conditions ( $\mathrm{RH}$ 30-40\%), assured by an automatic diffusion dryer (Tuch et al., 2009). An inlet with $50 \%$ aerodynamic cutoffs of $4 \mathrm{~nm}$ and $7 \mu \mathrm{m}$ for our flow conditions was used for laminar-flow aerosol sampling. Inlet lines ran from the measurement level (39 $\mathrm{m}$ a.g.l., about $10 \mathrm{~m}$ above the canopy height) to an air conditioned container at ground level. Housing for the researchers and a diesel generator that provided power supply were located respectively $0.33 \mathrm{~km}$ and $0.72 \mathrm{~km}$ to the west of the sampling site (downwind). A detailed description of the measurement site and surrounding can be found in Martin et al. (2010a).

\subsection{Instrumentation}

Aerosol particle scattering coefficients were measured using a three wavelength integrating nephelometer (TSI Model 3563) operating at 450, 550 and $700 \mathrm{~nm}$ (Anderson et al., 1996). Each six months the instrument was calibrated using filtered air and $\mathrm{CO}_{2}$. Sampling time varied between 1 and $5 \mathrm{~min}$. The backscatter shutter engine worked only a part 


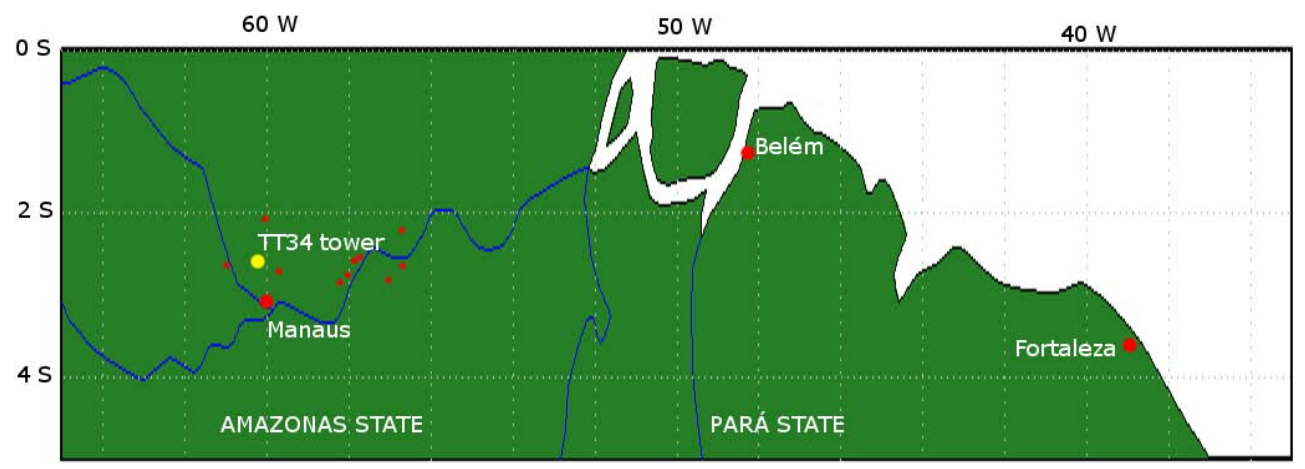

Fig. 1. The yellow circle marks the location of the TT34 measurement tower in the Sate of Amazonas, Brazil. The big red circles mark the position of some of the major cities in the Brazilian North and Northeast regions (more than 1.4 million inhabitants each). The small red circles mark the position of municipalities neighbor to the forest reserve (Rio Preto da Eva, Presidente Figueiredo, Novo Airão), and municipalities eastern to the forest reserve in the State of Amazonas (Barreirinha, Itapiranga, Nhamundá, Parintins, São Sebastião do Uatumã, Silves and Urucará).

Table 1. Uncertainties $\left(\delta \sigma_{\mathrm{s}}\right)$ estimated for $30 \mathrm{~min}$ averaging periods for scattering coefficients $\left(\sigma_{\mathrm{s}}\right)$ ranging between 1 and $100 \mathrm{Mm}{ }^{-1}$, for sub micrometer and super micrometer aerosol particles. Relative errors are shown in brackets.

\begin{tabular}{ccccccc}
\hline & \multicolumn{3}{c}{ Sub micrometer particles } & \multicolumn{3}{c}{ Super micrometer particles } \\
\hline$\sigma_{S} \mathrm{Mm}^{-1}$ & $\delta \sigma_{\mathrm{s}}(450) \mathrm{Mm}^{-1}$ & $\delta \sigma_{\mathrm{S}}(550) \mathrm{Mm}^{-1}$ & $\delta \sigma_{\mathrm{s}}(700) \mathrm{Mm}^{-1}$ & $\delta \sigma_{\mathrm{s}}(450) \mathrm{Mm}^{-1}$ & $\delta \sigma_{\mathrm{s}}(550) \mathrm{Mm}^{-1}$ & $\delta \sigma_{\mathrm{s}}(700) \mathrm{Mm}^{-1}$ \\
\hline 1 & $0.27(27 \%)$ & $0.20(20 \%)$ & $0.14(14 \%)$ & $0.39(39 \%)$ & $0.34(34 \%)$ & $0.31(31 \%)$ \\
10 & $0.80(8 \%)$ & $0.77(8 \%)$ & $0.78(8 \%)$ & $2.90(29 \%)$ & $2.90(29 \%)$ & $2.90(29 \%)$ \\
100 & $7.6(8 \%)$ & $7.5(7 \%)$ & $7.7(8 \%)$ & $28.9(29 \%)$ & $28.9(29 \%)$ & $28.9(29 \%)$ \\
\hline
\end{tabular}

of the time, between November 2009 and September 2010. Data were corrected for truncation errors according to Anderson and Ogren (1998), using the tabulated factors for total scatter as a linear function of Ångström exponent with no cutoff at the inlet. The average correction factor for truncation errors, calculated as the ratio between corrected and raw data, was $1.13 \pm 0.08$ for scattering coefficients at $550 \mathrm{~nm}$. As will be discussed on Sect. 4.5, this truncation correction factor fits well to Mie calculated correction factors, taken as the ratio between the simulated integral scattering coefficient $\left(0-180^{\circ}\right)$ and the simulated Nephelometer signal considering its angular truncation $\left(7-170^{\circ}\right)$ and illumination function. A constant correction factor of 0.982 was applied to backscatter measurements at $550 \mathrm{~nm}$, also according to Anderson and Ogren (1998). Due to the low aerosol loadings observed in Amazonia, aerosol particle optical data were averaged over $30 \mathrm{~min}$ intervals to improve statistics. Considering this averaging time, the detection limit of the Nephelometer at $550 \mathrm{~nm}$ is $0.14 \mathrm{Mm}^{-1}$ (Anderson et al., 1996). Uncertainties for nephelometer measurements as a function of averaging time and loading were calculated according to Sheridan et al. (2002) and references therein. Total uncertainty associated with scattering measurements was calculated for $30 \mathrm{~min}$ averaging times as the root-sum-square of five error sources: instrument noise $\left(5 \%\right.$ for $\sigma_{\mathrm{s}}(550)=1 \mathrm{Mm}^{-1}$ and $0.13 \%$ for $\left.\sigma_{\mathrm{s}}(550)=100 \mathrm{Mm}^{-1}\right)$; drift $(\sim 3 \%)$; uncertainty in calibra- tion $(7 \%)$; uncertainty associated to the truncation error correction $(2.2 \%$ for sub micrometer and $28 \%$ for super micrometer aerosols); uncertainty of adjusting scattering coefficients to standard temperature and pressure $(0.42 \%)$. Similar calculations were performed to estimate the uncertainty of backscattering measurements. Tables 1 and 2 show the total uncertainties on scattering $\left(\delta \sigma_{\mathrm{s}}\right)$ and backscattering measurements $\left(\delta \sigma_{\mathrm{bs}}\right)$.

Aerosol particle absorption was measured using a MAAP photometer (MultiAngle Absorption Photometry - Thermo Inc., Model 5012) (Petzold et al., 2005), operating in series with the Nephelometer. The MAAP reports black carbon (BC) concentrations at $637 \mathrm{~nm}$, which were converted to absorption coefficients assuming a mass absorption coefficient of $6.6 \mathrm{~m}^{2} \mathrm{~g}^{-1}$, used in the firmware of the instrument. Particle absorption coefficients were measured every minute, and a $5 \%$ correction was applied to the data to account for an adjustment of wavelength (Müller et al., 2011). $30 \mathrm{~min}$ averages were taken to improve statistics, with a resulting detection limit of $0.13 \mathrm{Mm}^{-1}$ (Petzold et al., 2005). Pressure and temperature measured inside the Nephelometer were used for adjusting scattering and absorption coefficients to $1013.25 \mathrm{mbar}$ and $0^{\circ} \mathrm{C}$. Between September and December 2008, integrating nephelometer measurements were discontinued due to the need of maintenance, and the MAAP ran by itself under the diffusion dryer inlet. In this case, the 
Table 2. Uncertainties $\left(\delta \sigma_{\mathrm{bs}}\right)$ estimated for $30 \mathrm{~min}$ averaging periods for backscattering coefficients $\left(\sigma_{\mathrm{bs}}\right)$ ranging between 0.1 and $10 \mathrm{Mm}^{-1}$, for sub micrometer and super micrometer aerosol particles. Relative errors are shown in brackets.

\begin{tabular}{ccccccc}
\hline & \multicolumn{3}{c}{ Sub micrometer particles } & \multicolumn{3}{c}{ Super micrometer particles } \\
\hline$\sigma_{\mathrm{bs}} \mathrm{Mm}^{-1}$ & $\delta \sigma_{\mathrm{bs}}(450) \mathrm{Mm}^{-1}$ & $\delta \sigma_{\mathrm{bs}}(550) \mathrm{Mm}^{-1}$ & $\delta \sigma_{\mathrm{bs}}(700) \mathrm{Mm}^{-1}$ & $\delta \sigma_{\mathrm{bs}}(450) \mathrm{Mm}^{-1}$ & $\delta \sigma_{\mathrm{bs}}(550) \mathrm{Mm}^{-1}$ & $\delta \sigma_{\mathrm{bs}}(700) \mathrm{Mm}^{-1}$ \\
\hline 0.1 & $0.23(230 \%)$ & $0.10(100 \%)$ & $0.17(170 \%)$ & $0.23(230 \%)$ & $0.10(100 \%)$ & $0.17(170 \%)$ \\
1 & $0.24(24 \%)$ & $0.13(13 \%)$ & $0.18(18 \%)$ & $0.24(24 \%)$ & $0.13(13 \%)$ & $0.19(19 \%)$ \\
10 & $0.76(8 \%)$ & $0.7(7 \%)$ & $0.8(8 \%)$ & $0.89(9 \%)$ & $0.9(9 \%)$ & $0.9(9 \%)$ \\
\hline
\end{tabular}

temperature of the aerosol sample measured at the diffusion dryer outlet and ambient pressure were used for STP corrections. A recent intercomparison of absorption photometers report MAAP noise levels up to $0.22 \mathrm{Mm}^{-1}$ for $1 \mathrm{~min}$ averaging time, unit to unit variability of $3 \%$ and $1 \%$ of the scattering seen as apparent absorption, depending on the aerosol loading and single scattering albedo (Müller et al., 2011). Assuming that the instrument noise decreases with the square root of averaging time, total uncertainties on aerosol absorption measurements, averaged each $30 \mathrm{~min}$ and under typical Amazonian conditions, was of $10 \%$.

In this work, scattering and backscattering coefficients will be preferably reported at $550 \mathrm{~nm}$, to ease the association with satellite based aerosol measurements like MODIS. Absorption and other aerosol properties that rely on absorption coefficients will be preferably presented at $637 \mathrm{~nm}$, to avoid additional errors related to the unknown absorption spectral dependency. In these cases, scattering coefficients will be interpolated to $637 \mathrm{~nm}$ using power law fits (c.f. Eq. 2).

Measurements of aerosol particle number size distribution, number concentration, mass and elemental composition were also taken, adding to the analysis and discussion of aerosol optical properties. Two fine mode mobility particle size spectrometers $(10-500 \mathrm{~nm})$ were interchangeably used: a TSI 3936 SMPS (Scanning Mobility Particle Sizer) and a custommade SMPS designed at Lund University according to EUSAAR (European Supersites for Atmospheric Aerosol Research) standards (Wiedensohler et al., 2012). Coarse mode particle number size distributions were measured using an OPC-Grimm Model 1.109 (300 nm-20 $\mu \mathrm{m}$ ) (Optical Particle Counter), whenever the instrument was available. Operating after the inlet, the actual cutoff of the OPC is at the optical diameter of $6 \mu \mathrm{m}$, assuming the aerosol density of $1.38 \mathrm{~g} \mathrm{~cm}^{-3}$ (Rissler et al., 2006). Particle number concentrations were interchangeably measured with condensation particle counters (TSI CPC models 3010, 3785, 3772). Stacked Filter Units (SFU) were used to collect fine mode $\left(D_{\mathrm{p}}<2.0 \mu \mathrm{m}\right)$ and coarse mode $\left(D_{\mathrm{p}}>2.0 \mu \mathrm{m}\right)$ aerosols, with integrating periods ranging from 2 to 5 days. Nuclepore filters were analyzed for particulate mass, following the measurement protocol of the US Environmental Protection Agency for weighing filters, and elemental composition, using particle-induced Xray emission and $\mathrm{X}$-ray fluorescence analysis.

\subsection{Meteorological parameters}

Meteorological parameters were measured at the K34 tower $\left(2^{\circ} 36.5450^{\circ} \mathrm{S}, 60^{\circ} 12.5580^{\circ} \mathrm{W}, 130 \mathrm{~m}\right.$ a.s.l. $)$, located $1.6 \mathrm{~km}$ to the south of the aerosol sampling site, and maintained by the National Institute for Research in the Amazon (INPA). Meteorological and radiation parameters were logged on a Campbell CR-10 data logger with a sampling interval of $30 \mathrm{~s}$ and stored as 10 to $30 \mathrm{~min}$ averages.

Along the aerosol measurement period, daytime quartiles of temperature, $\mathrm{RH}$ and wind velocity were respectively 24.5 to $29.5^{\circ} \mathrm{C}, 65$ to $90 \%$, and 1.38 to $2.78 \mathrm{~m} \mathrm{~s}^{-1}$. The corresponding nocturnal quartiles were, respectively, 23.1 to $25.6^{\circ} \mathrm{C}, 82$ to $95 \%$, and 1.24 to $2.31 \mathrm{~m} \mathrm{~s}^{-1}$. The quartiles of pressure were 993.5 to 996.7 mbar. A detailed description of climatological conditions can be found in Araújo et al. (2002). Here, only the meteorological parameters relevant for the interpretation of aerosol measurements will be discussed. Figure 2 shows the monthly accumulated precipitation between January 2008 and June 2011. Based on this figure, wet season is hereby defined as the period between January and June, and dry season between July and December. This definition may not be strictly correct from the climatological point of view, but for the purpose of the current aerosol dataset interpretation this is a reasonable choice.

Figure 3a shows the wind rose between January 2008 and June 2011. Easterly trade winds dominate at low levels, blowing over larger areas of undisturbed rain forest during the wet season. Nevertheless, during the dry season, biomass burning emissions from the Pará State $(\sim 1200 \mathrm{~km}$ from the sampling site) are transported through easterlies. In $13 \%$ of time, wind blew from the direction where the diesel generator was located $\left(240^{\circ}-330^{\circ}\right)$. Episodes of diesel generator emissions influencing the aerosol measurements were carefully inspected and removed from the data set, as will be further discussed in Sect. 3.3. Figure 1 on supplementary material shows the wind rose for the months of June and July between 2008 and 2011. The wind was southeastern $20 \%$ of the time, making the sampling site particularly susceptible to the urban plume of Manaus during these months. 


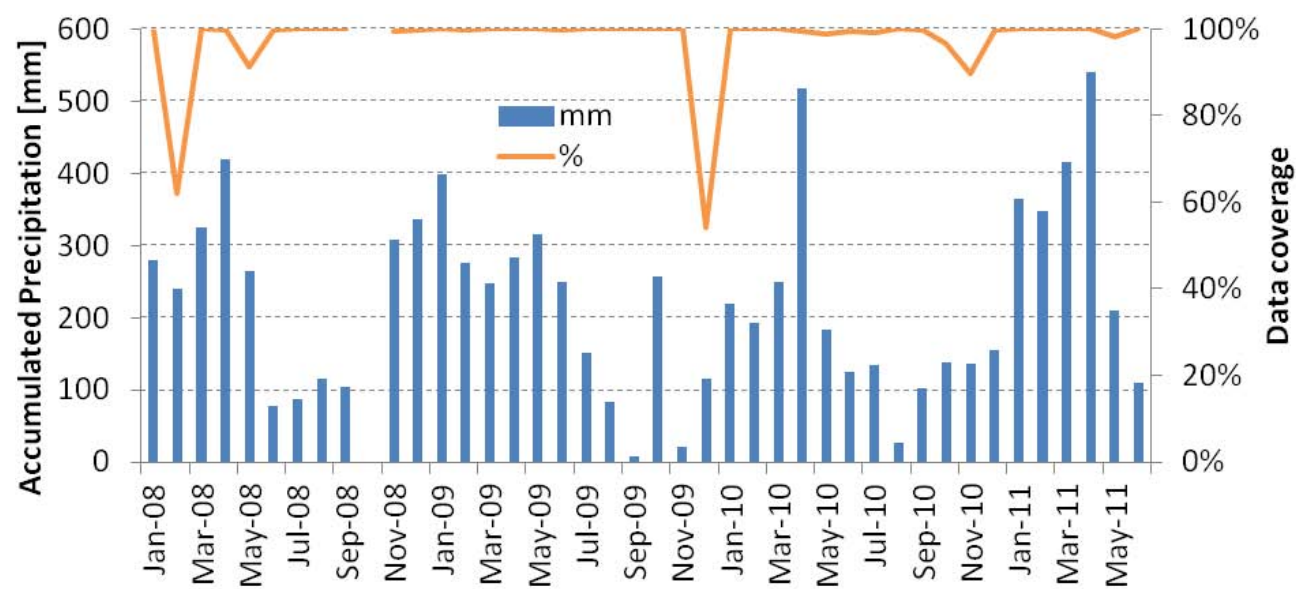

Fig. 2. Monthly accumulated precipitation measured at INPA's K34 tower from January 2008 to June 2011 . The line represents the percent data coverage for each month.
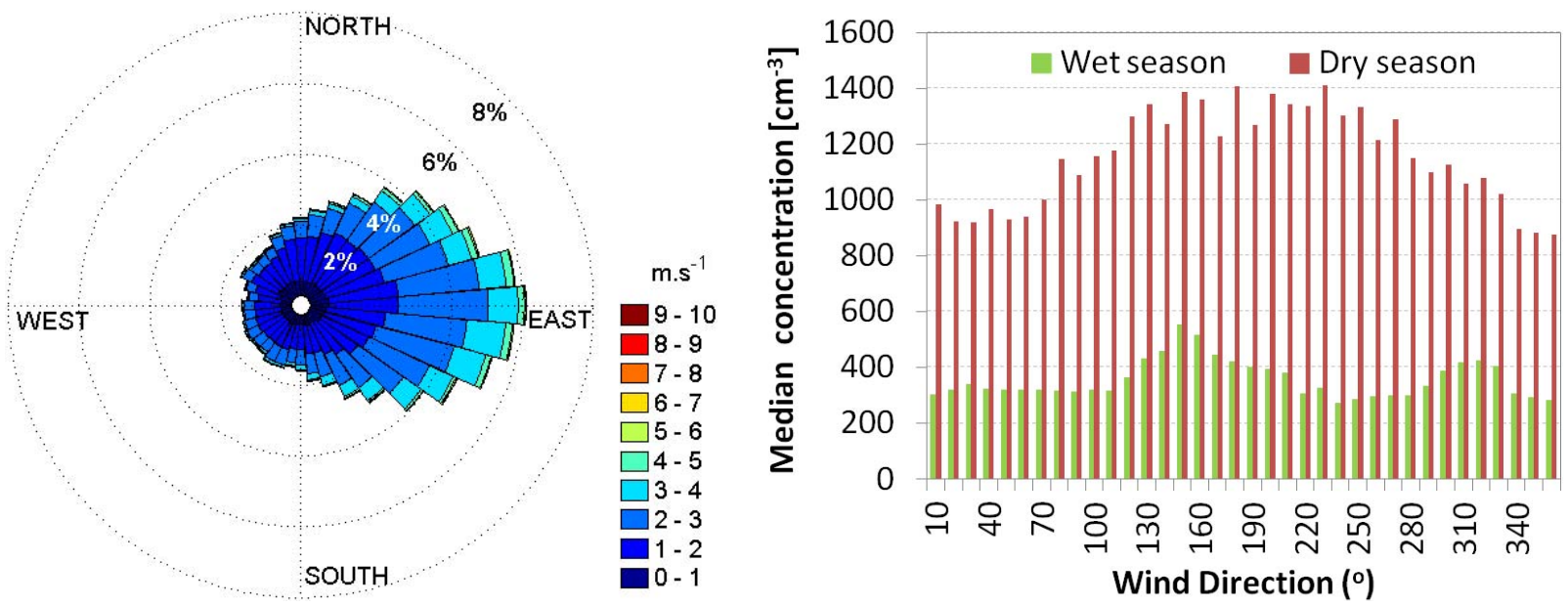

Fig. 3. (a) Wind rose plots for the period between January 2008 and June 2011. (b) Median aerosol particle number concentration as a function of wind direction for the wet season (January-June) and for the dry season (July-December). The Manaus city is located $60 \mathrm{~km}$ away in the southeast direction.

\section{Methods}

\subsection{Calculation of aerosol optical properties}

The first optical property that can be derived from scattering and absorption measurements is the aerosol particle extinction coefficient $\left(\sigma_{\mathrm{e}}\right)$ :

$\sigma_{\mathrm{e}}(\lambda)=\sigma_{\mathrm{s}}(\lambda)+\sigma_{\mathrm{a}}(\lambda)$,

where $\sigma_{\mathrm{s}}(\lambda)$ and $\sigma_{\mathrm{a}}(\lambda)$ are respectively the particle scattering and absorption coefficients measured at wavelength $\lambda$. In this work, particle extinction coefficients will be reported at $637 \mathrm{~nm}$, applying a power law interpolation over scattering coefficients to the wavelength in which absorption coefficients $\left(\sigma_{\mathrm{a}}\right)$ were measured.

Aerosol particle intensive properties are those that do not depend on the particle amount, and are related to intrinsic properties of the aerosols. In this study, four aerosol particle intensive properties will be investigated: the Ångström exponent for scattering $(\stackrel{a}{a})$, the hemispheric backscatter ratio $(b)$, the single scattering albedo $\left(\omega_{0}\right)$ and the aerosol forcing efficiency $(\triangle \mathrm{F} / \mathrm{AOD})$.

The particle scattering coefficient decreases monotonically with wavelength. In the literature it is usual to approximate this wavelength dependency by a power-law expression (Ångström, 1929):

$\sigma_{\mathrm{s}}(\lambda)=B \cdot \lambda^{-\stackrel{a}{a}}$,

where $\stackrel{a}{a}$ is known as the scattering Ångström exponent and $B$ is a constant known as the turbidity coefficient. Power laws were fitted to each $30 \mathrm{~min}$ averaged spectrum, and the negative of the slope was taken as the Angström exponent. Ångström exponents are indicative of the average size of the 
particle population. For monomodal particle number size distributions, Angström exponents greater than 2 indicate the predominance of particles around $0.1 \mu \mathrm{m}$ associated with urban pollution and biomass burning, and values smaller than 1 indicate large particles typically associated with sea salt and mineral dust (Schuster et al., 2006).

The hemispheric backscatter ratio $(b)$ is defined as:

$b(\lambda)=\frac{\sigma_{\mathrm{bs}}(\lambda)}{\sigma_{\mathrm{s}}(\lambda)}$,

where $\sigma_{\mathrm{bs}}$ is the particle backscatter coefficient, i.e., the volume scattering function integrated between $90^{\circ}$ and $180^{\circ}$, while the total scattering coefficient $\left(\sigma_{\mathrm{s}}\right)$ is integrated between $0^{\circ}$ and $180^{\circ}$. The backscatter ratio provides an indication of the angular distribution of the light scattered by aerosol particles, a key property to determine the aerosol direct radiative forcing (Andrews et al., 2006). Some studies report an inverse relationship between $b$ and particle size (e.g., Collaud Coen et al., 2007). Other studies argue that changes in the backscattering ratio can also be driven by particle shape, especially for data taken under dry conditions, when particle sphericity is not certain (Doherty et al., 2005). Moreover, a recent study by Ma et al. (2012) indicated a significant dependency of the backscatter ratio on the aerosol mixing state.

The single scattering albedo (SSA) is a measure of the aerosol particle scattering strength relative to extinction. The scattering coefficients at the integrating nephelometer wavelengths $(450,550,700 \mathrm{~nm})$ were interpolated logarithmically to the wavelength in which absorption coefficients $\left(\sigma_{\mathrm{a}}\right)$ were measured to obtain the single-scattering albedo $\left(\omega_{0}\right)$ at $637 \mathrm{~nm}$ :

$\omega_{0}=\frac{\sigma_{\mathrm{s}}}{\sigma_{\mathrm{s}}+\sigma_{\mathrm{a}}}$.

For purely scattering aerosol particles (e.g., ammonium sulfate) $\omega_{0}$ approaches 1.0. In situ observations of dry aerosol SSA typically show values in the range $0.80-0.98$ for urban aerosols (Anderson et al., 2003), 0.72-0.88 for fresh biomass burning smoke (Magi et al., 2003) and 0.88-0.99 for coarse mode dominated mineral dust (Anderson et al., 2003).

The particle SSA and the backscatter ratio can be used to calculate the top of the atmosphere aerosol forcing $(\Delta \mathrm{F})$ per unit aerosol optical depth (AOD), also called aerosol forcing efficiency (e.g. Kaufman et al., 2005; Sheridan and Ogren, 1999):

$\frac{\Delta F}{\mathrm{AOD}}=-D S_{0} T_{\mathrm{at}}^{2}\left(1-A_{\mathrm{c}}\right) \omega \beta\left\{\left(1-R_{\mathrm{s}}\right)^{2}-\left(\frac{2 R_{\mathrm{s}}}{\beta}\right)\left[\frac{1}{\omega}-1\right]\right\}$,

where $D$ is the day length (set to 0.5 in the tropics); $S_{0}=1370 \mathrm{~W} \mathrm{~m}^{-2}$ is the solar constant; $T_{\text {at }}$ is the atmospheric transmissivity (set to 0.76 ); $A_{\mathrm{c}}$ is the fractional cloud amount; $R_{\mathrm{S}}$ is the surface reflectance; $\omega$ and $\beta$ are the spectrally weighted particle SSA and backscatter fraction, respectively (Haywood and Shine, 1995). Here, the aerosol layer is assumed to be optically thin, $\beta$ is independent of the zenith angle, and $T_{\text {at }}$ is assumed to follow Beer's Law. The surface reflectance at the tower site was based on IGBP (International Geosphere Biosphere Programme) broadband albedo from CERES (Clouds and the Earth's Radiant Energy System), $R_{\mathrm{S}}=0.13(300-5000 \mathrm{~nm})$. The daily time series of cloud fraction at the tower site was taken from MODIS measurements on Terra and Aqua satellites (global $1^{\circ} \times 1^{\circ}$ daily level-3 cloud fraction, day only). $\sigma_{\mathrm{s}}(\lambda)$ and $b(\lambda)$ were calculated trough extrapolation of the spectral dependence in the range $450-700 \mathrm{~nm}$ to the broadband range $(300-5000 \mathrm{~nm}) . \sigma_{\mathrm{a}}(\lambda)$ was calculated assuming a power law dependency on $\lambda$, with an absorption Ångström exponent of 1.3 (Rizzo et al., 2011). Spectrally weighted $\omega$ and $\beta$ were calculated based on global spectral irradiance $D(\lambda)$ for a sun-facing $37^{\circ}$ tilted surface and air mass coefficient of 1.5 (Hulstrom et al., 1985):

$\beta=\frac{\int b(\lambda) D(\lambda) d \lambda}{\int D(\lambda) d \lambda}$ and $\frac{\int \omega_{0}(\lambda) D(\lambda) d \lambda}{\int D(\lambda) d \lambda}$.

It is important to emphasize that the results presented here refer to dry aerosols $(\mathrm{RH}<40 \%)$. Aerosol particle optical properties may change significantly under ambient humidity conditions. Rissler et al. (2006) and Zhou et al. (2002) state that Amazonian aerosols are only moderately hygroscopic, with growth factors ranging between $1.0-1.3$ for $100 \mathrm{~nm}$ particles at $90 \% \mathrm{RH}$. The impact of hygroscopic growth on the particle scattering coefficients in Amazonia has been investigated by Kotchenruther and Hobbs (1998), reporting an average increase of $16 \%$ on scattering and a decrease of 10 to $20 \%$ on backscatter ratio when RH rises from 30 to $80 \%$. The dependence of particle absorption coefficients as a function of RH is not currently known. On one hand, the water uptake by aerosol increases the particle diameter, enhancing the focusing effect (Bohren and Huffman, 2008), causing an increase of particle absorption coefficients. On the other hand, the refractive index of water is smaller than that of the non-absorbing particle components, which may cause a decrease on particle absorption coefficients depending on particle size (Nessler et al., 2005). Modeling studies for a highly polluted area in China report absorption humidification factors ranging between 0.9 and 1.2 at $80 \% \mathrm{RH}$ (Cheng et al., 2008). The impact of RH on scattering and absorption reflect on the particle SSA and forcing efficiency. Anderson et al. (1999) reports increase of $2-5 \%$ on particle SSA and a decrease of $10-15 \%$ on aerosol forcing efficiency along the shift from low to high $\mathrm{RH}$ conditions.

\subsection{Optical closure study}

An optical closure study was done for aerosol particle properties measured between 1 July-14 August 2009 period at which particle number size distribution measurements of the fine and coarse aerosol were available. A Mie code based on Bohren and Huffman (1998) was used to calculate the optical particle properties for the entire aerosol population, 
assuming homogeneous spherical particles. Using particle number size distribution, refractive index and wavelength of incident light as inputs, the code calculates aerosol particle scattering, backscattering and absorption coefficients, and also simulates the measured particle scattering signal considering the 7 to $170^{\circ}$ integrating angle range of the TSI 3563 nephelometer and its non Lambertian illumination function (Anderson et al., 1996).

Sub micrometer particle aerosol number size distributions were measured using a custom-made SMPS $(10-500 \mathrm{~nm})$. For the accumulation and part of the coarse mode, an OPCGrimm ( $300 \mathrm{~nm}-6 \mu \mathrm{m}$ under operation conditions) was used. Optical particle size spectrometers measure optical particle diameters, based on the assumption that the scattered light intensity is a monotonic function of particle size (Hinds, 1999). The calibration of these instruments is typically performed with monodisperse polystyrene latex particles, which have a refractive index of 1.59-0i. The refractive index of ambient aerosols is usually lower than that, resulting in underestimation of particles sizes (Heim et al., 2008). Particularly, the OPC-Grimm measures scattering at $655 \mathrm{~nm}$, with collecting angles between 29.5 and $150.5^{\circ}$. Response correction functions for the measured optical particle number size distributions were calculated using the same Mie code assuming a range of refractive indexes, and a look-up table was produced. The correction affects the bin boundaries of the OCP-derived optical diameter, resulting in a shift of geometric mean diameters and adjustment of normalized number concentrations, according to bin width change. Calculations have shown that $1 \mu \mathrm{m}$ particles can be up to $30 \%$ underestimated, depending on its refractive index. The correction factors increase with the imaginary part of the refractive index, particularly for super micrometer particles.

Particle number size distributions of the mobility and optical particle size spectrometers were $60 \mathrm{~min}$ averaged, and used as input to the Mie code. A range of refractive indexes (1.34 to 1.80 and 0 to $0.03 \mathrm{i}$, with steps of 0.005 and 0.0005 respectively) was tested for each combined particle number size distribution, with the corresponding OPC response adjustment taken from the mentioned look up table of correction factors. Corrected particle number size distributions were truncated at the optical diameter of $6 \mu \mathrm{m}$. The refractive index representative of each size distribution was iteratively determined by means of matching the Mie code simulation for the Nephelometer signal, which takes into account its truncation error and illumination function, and the measured scattering and absorption coefficients within $10 \%$. This confidence range is similar to the usual expected data quality of particle size spectrometers (Wiedensohler et al., 2012). Similar iterative methods for aerosol refractive index retrieval have been reported before, e.g., Guyon et al., 2003; Hand and Kreidenweis, 2002; Mack et al., 2010.

\subsection{Classification of aerosol external sources}

In spite of the fact that the measurement tower is located in an area of undisturbed primary forest, it sporadically received the influence of external aerosol sources: (1) local pollution (diesel generator and occasional vehicles transporting researchers and equipment); (2) Manaus urban plume; (3) regional transport of biomass burning emissions; (4) soil dust and biomass burning transport from northern and equatorial Africa. The local pollution source and the Manaus urban plume were most significant during the wet season, occasionally affecting pristine conditions of low aerosol particle mass concentration. Figure $3 \mathrm{~b}$ shows median aerosol particle number concentration as a function of wind direction, in which the signal of the Manaus urban plume $\left(120-190^{\circ}\right)$ and of the diesel generator $\left(270-340^{\circ}\right)$ is clear during the wet season. The same figure shows that during the dry season the transport of regional biomass burning emissions overcame all other external sources.

Local pollution episodes were characterized by abrupt changes in particle number concentrations (increase rate $>500 \mathrm{~cm}^{-3} \mathrm{~h}^{-1}$ ) and absorption coefficients (increase rate $>0.2 \mathrm{Mm}^{-1} \mathrm{~h}^{-1}$ ), typically lasting from $30 \mathrm{~min}$ to $3 \mathrm{~h}$. Periods of western and northwestern wind direction (270 to $340^{\circ}$ ), where the diesel generator was located, were scrutinized, and the aerosol particle data associated with local pollution was excluded from the analysis, corresponding to $2 \%$ of the measurement period.

The Manaus urban plume reached the sampling site sporadically, with effects lasting from $4 \mathrm{~h}$ to a whole day. The greater time extent of the Manaus plume compared to that of the generator is due to their respective horizontal scales. Episodes were characterized by a consistent increase on aerosol particle number concentrations, scattering and absorption coefficients, as will be further discussed on Sect. 4.6.1. Periods with local wind directions coming from Manaus city $\left(120-190^{\circ}\right)$ were carefully inspected, and HYSPLIT back-trajectories (Draxler and Rolph, 2012; Rolph, 2012) were calculated to verify the origin or air masses reaching the site. Back-trajectories were based on meteorological REANALYSIS dataset, with $24 \mathrm{~h}$ total run time, starting at $50 \mathrm{~m}$ height. Confirmed Manaus urban plume transport events corresponded to $1.5 \%$ of the measurement period, and were not removed from the data analysis.

Transport of biomass burning emissions from Eastern Amazonia occurred all through the dry season period, being the strongest non-biogenic aerosol source reaching the measurement site. In the dry season, pollution from biomass smoke typically accounts for $>90 \%$ of the fine particles and $\sim 50 \%$ of the coarse particle mass (Martin et al., 2010b). Table 3 shows the fire spots detected for the dry seasons of 2008, 2009 and 2010 (July-December) in Amazonia by the polar satellites NOAA 15-19 and AQUA, and by the geostationary satellite GOES-12, operationally processed by the Brazilian National Institute of Spatial Research 
Table 3. Fire spots detected during the dry season (Jul-Dec) in the Amazonas State, Pará State, Legal Amazonia area, forest reserve neighbor municipalities (Manaus, Rio Preto da Eva, Presidente Figueiredo, Novo Airão), and municipalities eastern to the forest reserve in the State of Amazonas (Barreirinha, Itapiranga, Manaus, Nhamundá, Parintins, São Sebastião do Uatumã, Silves and Urucará). Source: CPTEC/INPE.

\begin{tabular}{cccccc}
\hline & Amazonas State & Pará State & Legal Amazonia & Neighbor districts & Eastern districts \\
\hline Dry 2008 & 11038 & 103833 & 346983 & 112 & 269 \\
Dry 2009 & 14576 & 103265 & 246513 & 813 & 2244 \\
Dry 2010 & 20613 & 164618 & 686670 & 367 & 1023 \\
\hline
\end{tabular}

Table 4. Periods of influence of African particle advection from Feb to May 2008, reported by Baars et al. (2011).

\begin{tabular}{ll}
\hline Period of influence & Aerosol type \\
\hline 25 Feb-01 Mar 2008 & Smoke + Dust \\
15-16 Mar 2008 & Smoke + Dust \\
08 Apr 2008 & Smoke + Dust \\
08-11 May 2008 & Mostly Dust \\
\hline
\end{tabular}

(CPTEC/INPE). A spot indicates the occurrence of fire in one pixel, i.e., 1-20 $\mathrm{km}^{2}$ depending on the satellite resolution. The fire counts shown here are overestimated, since the same burning event can occasionally be detected by two satellites in different positions (a couple of $\mathrm{km}$ difference), in a way that a single fire spot may be counted twice. Fire counts in the Amazonas State, where the ZF2 forest reserve is located, are $90 \%$ smaller than the fire counts in its eastern neighbor Pará State. Fire counts in the legal Amazonia area significantly increased in 2010, probably due to the severe drought that occurred in that year (Lewis et al., 2011). In 2009, fire spots at districts neighbor and Eastern to the ZF2 forest reserve showed a noteworthy increase, echoing on aerosol optical properties, as will be further discussed.

There is evidence that the research site was affected at times by soil dust transport from northern Africa and biomass burning from equatorial Africa. This is supported by satellite observations (Kaufman et al., 2005), LIDAR measurements (Ansmann et al., 2009; Baars et al., 2011); back-trajectories analysis and surface measurements (Ben-Ami et al., 2010; Prenni et al., 2009). At the research site, African mineral dust advection can be traced by increased concentrations of crustal elements $\mathrm{Al}, \mathrm{Si}$, Ti and Fe on fine mode aerosol filter samples. African mineral dust transport events are typical to the months of March and April, while advection of African biomass burning aerosols occurs also in the dry season (Martin et al., 2010b). The periods of influence of African aerosols advection in the wet season of 2008 are well documented by Baars et al. (2011), and will be used in this study to calculate statistics for aerosol properties under this condition (Table 4). According to the same study, the episodes of African aerosol advection that occurred in the wet season of 2008 showed dust fractions ranging from 20 to $100 \%$. The non-dust fraction was mostly related to aged biomass burning aerosols from Africa. Based on the spectral dependency of LIDAR ratios, the authors state that the influence of marine aerosol particles and local pollution was not significant during those events.

\section{Results and Discussion}

\subsection{Variability of aerosol optical properties}

The complete time series of aerosol particle scattering and absorption coefficients is illustrated in Fig. 4. Year to year variability on aerosol particle optical properties occurred mostly due to deviations on the amount of precipitation and biomass burning sources strength. Particle scattering coefficients increased substantially under the influence of biomass burning particles. This is a consequence of enhanced concentration of fine mode particles in the dry season, which are more efficient to scatter light in comparison to the coarse mode dominated biogenic particles in the wet season. Lower removal by precipitation (from wet to dry season the average precipitation rates decreased from 10 to $4 \mathrm{~mm} \mathrm{day}^{-1}$ ) may also play a role on particle scattering increase in the dry season.

Table 5 shows that the 2009 dry season had median values of aerosol particle scattering and absorption respectively $110 \%$ and $23 \%$ greater than the values observed during the dry season of 2010. This may be an outcome of the increased occurrence of fire spots at neighbor municipalities and at districts located to the East of the forest reserve during the dry season of 2009 in comparison to 2010 (Table 3). The same table shows that in 2010 there was profusion of fires, but in the Amazon region as a whole. The fact that median scattering coefficients were much more enhanced than absorption coefficients in 2009 can be surprising at first. However, during the dry season, the air masses reaching the measurements site constitute a blend of smoke plumes from different fire stages and ages. Reid et al. (2005) states that deforestation fires can smolder for days, producing particles at high emission factor rates with small black carbon content, thereby decreasing the aerosol absorption and increasing aerosol scattering of the original plume. Evidences show a tendency of particle scattering increase with plume age, due to physical and chemical atmospheric processes acting towards particle size increase, mass increase and gas-to-particle exchanges 
Table 5. Year to year and seasonal variability on aerosol particle scattering and absorption. The percent data coverage is also shown.

\begin{tabular}{ccccccccc}
\hline & \multicolumn{3}{c}{ Aerosol Scattering 550 $\mathrm{nm}\left[\mathrm{Mm}^{-1}\right]$} & \multicolumn{3}{c}{ Aerosol Absorption 637 $\left.\mathrm{nm}^{2} \mathrm{Mm}^{-1}\right]$} \\
\cline { 2 - 9 } & median & 1st quartile & 3rd quartile & coverage & median & 1st quartile & 3rd quartile & coverage \\
\hline Dry 2008 & 15 & 11 & 21 & $36.4 \%$ & 1.86 & 1.13 & 2.92 & $51.1 \%$ \\
Dry 2009 & 35 & 19 & 61 & $98.9 \%$ & 3.69 & 2.06 & 6.07 & $95.1 \%$ \\
Dry 2010 & 16 & 9.2 & 32 & $84.8 \%$ & 3.00 & 1.15 & 5.62 & $98.4 \%$ \\
Wet 2008 & 5.5 & 2.8 & 9.3 & $59.9 \%$ & 0.34 & 0.16 & 0.80 & $59.3 \%$ \\
Wet 2009 & 8.1 & 4.6 & 14 & $58.6 \%$ & 0.41 & 0.22 & 0.88 & $85.6 \%$ \\
Wet 2010 & 7.5 & 4.7 & 12 & $82.3 \%$ & 0.95 & 0.34 & 2.22 & $84.0 \%$ \\
Wet 2011 & 3.9 & 2.1 & 6.6 & $51.1 \%$ & 0.37 & 0.17 & 0.79 & $67.0 \%$ \\
\hline
\end{tabular}

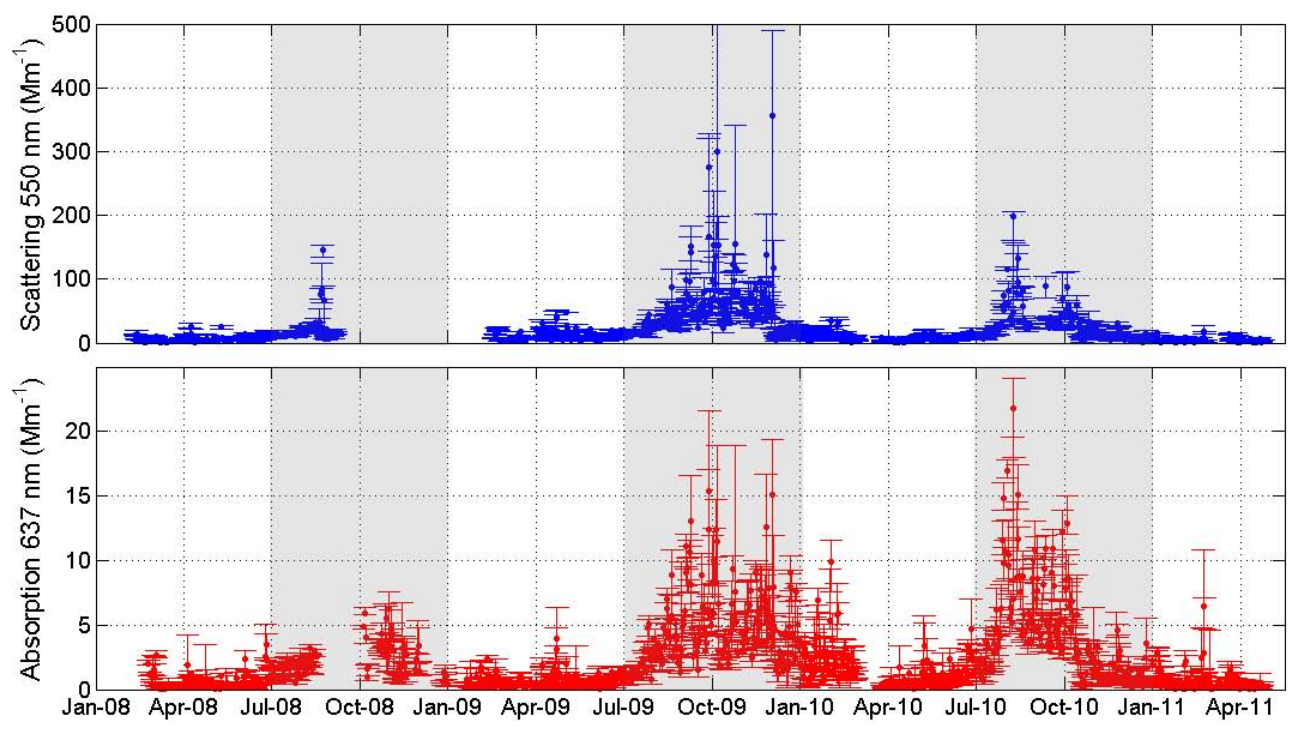

Fig. 4. Daily medians of aerosol particle scattering coefficients at $550 \mathrm{~nm}$ (a) and of aerosol particle absorption coefficients at $637 \mathrm{~nm}$ (b), from February 2008 to May 2011. Error bars represent first and third quartiles. Shaded areas represent the dry season period.

(Reid et al., 2005 and references therein). Conversely, in situ observations of biomass burning plumes indicate that black carbon concentrations typically decrease by only $10-50 \%$ from fresh smoke to regional haze (Capes et al., 2008; Reid et al., 1998), through dilution with cleaner background air. Therefore, this is reasonable that particle scattering and absorption coefficients vary by different factors, depending on the plume characteristics and atmospheric conditions.

Another feature shown in Table 5 is that the median value of the particle absorption in the wet season of 2010 was approximately 2.6 times greater than the values observed during the other years of measurements. Between January and February 2010, eight periods of elevated absorption coefficients $\left(>2 \mathrm{Mm}^{-1}\right.$ ) were observed, lasting continuously from 2 to 6 days. No influence of the Manaus urban plume or fire spots in nearby districts was detected in this period. This time scale is typical of African aerosol advection events, and this is a possible explanation for the observed increase of absorption coefficients in the wet season of 2010. Figure 5 shows particle absorption coefficients averaged according to aerosol filter integration times (2-5 days), as well as fine mode crustal elements concentration ( $\mathrm{Al}, \mathrm{Si}, \mathrm{Ti}, \mathrm{Fe})$ and fine mode potassium concentration. Potassium in the fine mode has been associated both to biomass burning and to biogenic sources in the Amazon (Artaxo et al., 1994). For simplicity, in Fig. 5 only the data between Jan and May of each year is shown, since this is the period when most African advection events occur. The February 2008 African advection event (refer to Table 4) is clearly depicted, with increased concentrations of fine mode crustal elements and potassium, as well as increased particle absorption. The April 2008 advection event had a clear effect over the aerosol filter samples, but not over the particle absorption coefficients. The reason for that is unknown, but could be related to the fact that occasionally mineral dust particles are internally mixed with organic material, possibly affecting the aerosol optical properties (Pöschl et al., 2010). Between January and February 2010, Figure 5 shows enhancements of potassium in the fine mode associated with particle absorption. This could be explained by African advection of aged biomass 


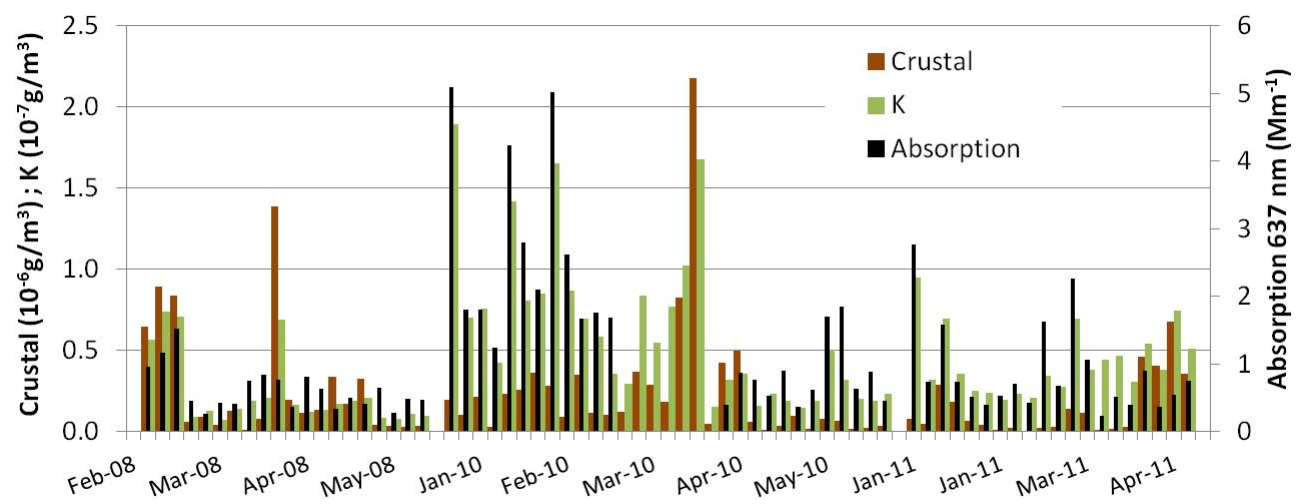

Fig. 5. Aerosol particle mass concentrations of fine mode $\left(\mathrm{PM}_{2}\right)$ crustal elements $\left(\mathrm{Al}, \mathrm{Si}, \mathrm{Ti}, \mathrm{Fe}\right.$, in $\left.10^{-6} \mathrm{~g} \mathrm{~m}^{-3}\right)$ and potassium $(\mathrm{K}$, in $10^{-7} \mathrm{~g} \mathrm{~m}^{-3}$ ), and particle absorption coefficients at $637 \mathrm{~nm}$ averaged according to filter integration times. Only data between January and May of each year is shown.

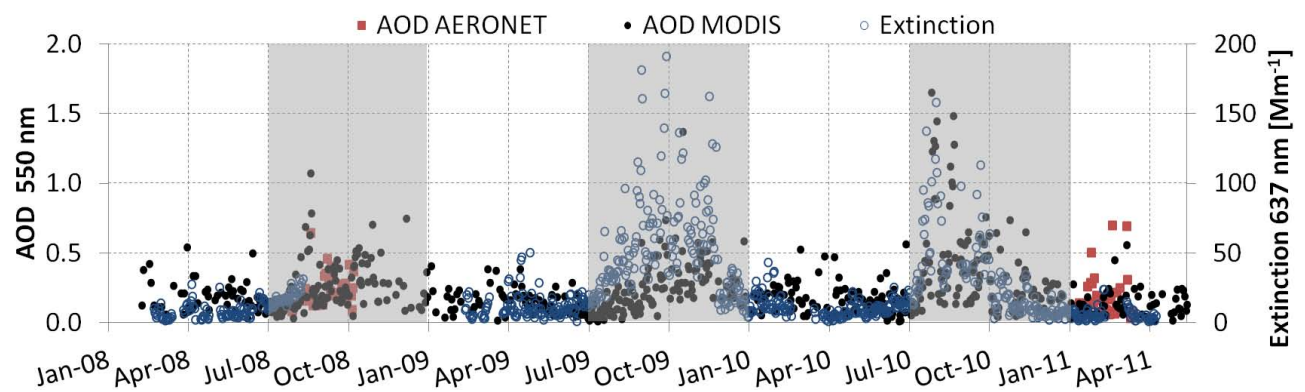

Fig. 6. Daily averages of aerosol optical depth (AOD) observations from MODIS (TERRA-AQUA), AERONET (Manaus) and in situ extinction measurements above the canopy. AOD observations from MODIS were integrated inside an area with $40 \mathrm{~km}$ radius around the in situ measurement site. AOD observations from AERONET are level 2.0 in 2008 Jul-Oct and level 1.5 in January-April 2011, and were interpolated to $550 \mathrm{~nm}$ using $\mathrm{AOD}(500)$ and the Ångström exponent between 440 and $675 \mathrm{~nm}$. Shaded areas represent the dry season period.

burning particles, but the possibility of biogenic aerosols affecting the absorption coefficients cannot be ruled out. In accordance with that, Guyon et al. (2004) estimated that $35 \%$ of light absorption could be attributed to biogenic particles in another Amazonian forest site. In March 2010 the absorption data coverage was very poor $(14 \%)$.

Figure 6 puts together the time series of in-situ aerosol particle extinction, calculated from scattering and absorption coefficients measured above the canopy, and the time series of aerosol optical depth (AOD) from MODIS (TERRA-AQUA) and from AERONET sun photometer in Manaus. It is clear that the aerosol particle extinction measured right above the canopy echoes in the remotely sensed AOD in the entire atmospheric column. It is worth noticing that sometimes the remotely sensed AOD increased without a corresponding enhancement on in situ aerosol extinction. This is an indication that not all advected aerosol plumes, originated either at Africa or inside the Amazon Basin, reached the measurement site just above the canopy top. Measurements of micrometeorological parameters like vertical wind speed, equivalent potential temperature or atmospheric stability would help to im- prove aerosol data analysis in these cases, but unfortunately were not available for this site.

In spite of the year to year variability, the dataset shows a clear seasonal pattern, with higher aerosol particle concentrations during the dry season (July-December) in comparison to the wet season (January-June). From wet to dry season, median aerosol particle scattering $(550 \mathrm{~nm})$ and absorption $(637 \mathrm{~nm})$ coefficients increased from 6.3 to $22 \mathrm{Mm}^{-1}$, and from 0.5 to $2.8 \mathrm{Mm}^{-1}$, respectively (Table 6). Figure 7 show box plots for particle scattering and absorption coefficients, calculated for each 10 Julian days between February 2008 and May 2011. Besides the seasonal variation related to dry and wet seasons, there is a clear influence of mineral dust and aged biomass burning aerosol advection from Africa over the particle absorption coefficients between January and March, while the particle scattering coefficients were not significantly affected. This leads to decreased SSA, reaching values as low as 0.55 in March (Fig. 7). That explains, in part, the reason why the median SSA value is 0.88 both for wet and dry season (Table 6). This median value is in accordance with LIDAR derived SSA values in the main aerosol layer below $2.5 \mathrm{~km}$ height at the same forest reserve 
Table 6. Average, standard deviation, 1st quartile, median, 3rd quartile, and number of observations for aerosol particle scattering coefficients $\left(\sigma_{\mathrm{s}}\right)$ and backscatter ratios $(b)$ at 450,550 and $700 \mathrm{~nm}$, absorption coefficients $\left(\sigma_{\mathrm{a}}\right)$ at $637 \mathrm{~nm}$, Ångström exponent for scattering $\left(\stackrel{\circ}{4}_{450-700}\right)$ and single scattering albedo at $637 \mathrm{~nm}\left(\omega_{0}\right)$, based on 30 min averages.

\begin{tabular}{llccccc}
\hline & & Avg \pm stdev & 1st quart & Median & 3rd quart & $N$ \\
\hline$\sigma_{\mathrm{S}}(450) \mathrm{Mm}^{-1}$ & Wet season & $11 \pm 9$ & 4.7 & 8.3 & 14 & 19155 \\
& Dry season & $50 \pm 64$ & 17 & 31 & 59 & 17581 \\
& All data & $29 \pm 49$ & 7.3 & 15 & 31 & 36736 \\
$\sigma_{\mathrm{S}}(550) \mathrm{Mm}^{-1}$ & Wet season & $8.1 \pm 7.2$ & 3.4 & 6.3 & 11 & 19155 \\
& Dry season & $36 \pm 48$ & 12 & 22 & 42 & 17581 \\
& All data & $21 \pm 36$ & 5.4 & 11 & 23 & 36736 \\
$\sigma_{\mathrm{S}}(700) \mathrm{Mm}^{-1}$ & Wet season & $5.4 \pm 5.1$ & 2.3 & 4.2 & 7.0 & 19155 \\
& Dry season & $18 \pm 23$ & 7.0 & 11 & 20 & 17581 \\
& All data & $11 \pm 17$ & 3.4 & 6.5 & 12 & 36736 \\
$b(450)$ & Wet season & $0.13 \pm 0.05$ & 0.11 & 0.13 & 0.15 & 6571 \\
& Dry season & $0.13 \pm 0.02$ & 0.12 & 0.13 & 0.14 & 4751 \\
& All data & $0.13 \pm 0.04$ & 0.11 & 0.13 & 0.14 & 11322 \\
$b(550)$ & Wet season & $0.15 \pm 0.05$ & 0.13 & 0.15 & 0.17 & 6571 \\
& Dry season & $0.15 \pm 0.03$ & 0.14 & 0.15 & 0.17 & 4751 \\
& All data & $0.15 \pm 0.04$ & 0.13 & 0.15 & 0.17 & 11322 \\
$b(700)$ & Wet season & $0.20 \pm 0.07$ & 0.16 & 0.19 & 0.22 & 6571 \\
& Dry season & $0.20 \pm 0.04$ & 0.18 & 0.20 & 0.22 & 4751 \\
$\sigma_{\mathrm{a}}(637) \mathrm{Mm}^{-1}$ & All data & $0.20 \pm 0.06$ & 0.17 & 0.20 & 0.22 & 11322 \\
& Wet season & $1.0 \pm 1.4$ & 0.2 & 0.5 & 1.1 & 24158 \\
& Dry season & $3.9 \pm 3.6$ & 1.4 & 2.8 & 5.2 & 19567 \\
$a_{450-700}$ & All data & $2.3 \pm 3.0$ & 0.4 & 1.1 & 3.0 & 43725 \\
$\omega_{0}(637)$ & Wet season & $1.48 \pm 1.12$ & 1.02 & 1.40 & 1.80 & 19155 \\
& Dry season & $1.70 \pm 0.41$ & 1.43 & 1.73 & 1.98 & 17581 \\
& All data & $1.59 \pm 0.86$ & 1.22 & 1.58 & 1.92 & 36736 \\
& Wet season & $0.86 \pm 0.09$ & 0.81 & 0.88 & 0.93 & 15283 \\
& Dry season & $0.87 \pm 0.06$ & 0.84 & 0.88 & 0.91 & 15766 \\
& All data & $0.86 \pm 0.08$ & 0.83 & 0.88 & 0.91 & 31049 \\
\hline & & & & & &
\end{tabular}

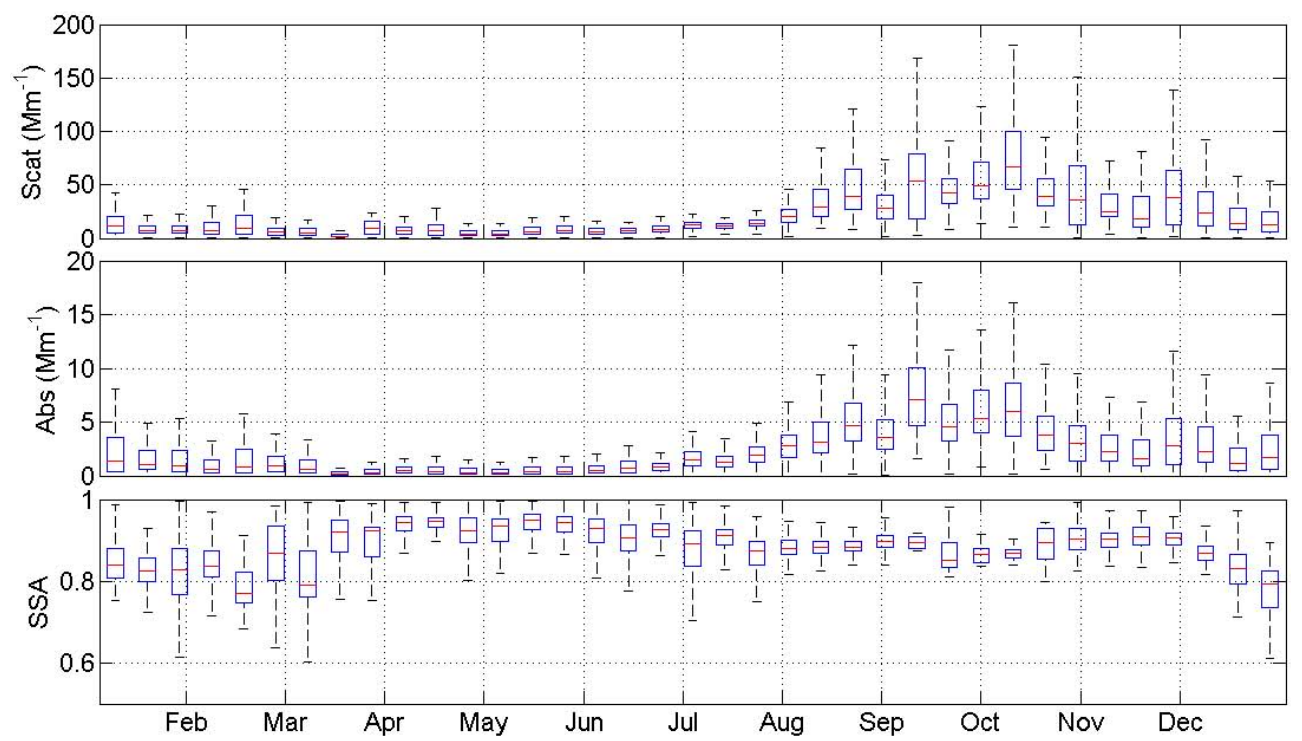

Fig. 7. Median 2008-2011 seasonal cycle for particle scattering coefficients at $550 \mathrm{~nm}$, particle absorption coefficients at $637 \mathrm{~nm}$, and particle single scattering albedo (SSA) at $637 \mathrm{~nm}$. Statistics were calculated for each 10 Julian days. The box lines represent the lower quartile, median and upper quartile values. Whiskers extend within 1.5 times the interquartile range. 


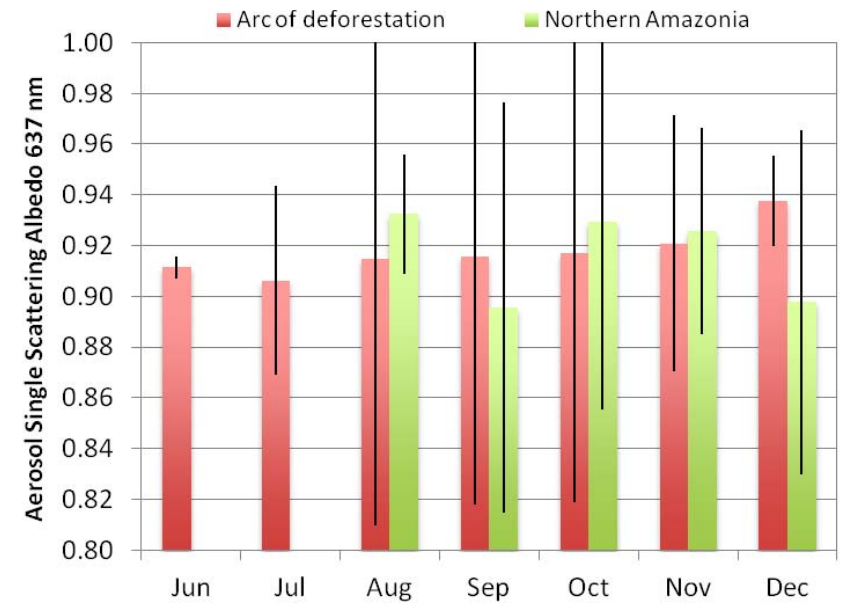

Fig. 8. Monthly averages of AERONET retrieved single scattering albedo between 1993 and 2011 at seven different locations in Amazonia: Ji Paraná, Alta Floresta, Rio Branco (arc of deforestation), Balbina, Belterra, Santarém, Manaus (northern Amazonia). All data is level 2, with exception to 9 Manaus data points in 2008, which are level 1.5. Particle SSA values observed in the AERONET wavelengths were interpolated to $637 \mathrm{~nm}$. Error bars indicate standard deviations.

(0.82-0.96) (Baars et al., 2012). The particle SSA measured in situ is also consistent with AERONET observations in the atmospheric column (Fig. 8), considering that under ambient RH conditions the in situ dry aerosol particle SSA values would increase by $2-5 \%$ (Anderson et al., 1999). Figure 8 shows monthly statistics for AERONET aerosol particle SSA between 1993 and 2011 at 7 different locations in Amazonia: 3 of them situated at the region of the so-called arc of deforestation (Ji Paraná, Alta Floresta and Rio Branco), and 4 of them at Northern Amazonia, far from direct impact of forest fires (Balbina, Belterra, Santarém and Manaus). There are few observations in the wet season because the inversion algorithm for particle SSA retrieval requires a minimum aerosol optical thickness of 0.4 (Holben et al., 2006), which is much greater than the average value of 0.15 observed in the wet season (Schafer et al., 2008). Also, in the wet season the steady cloud cover in Amazonia prevents the measurements of sky radiances. For the same reasons, AERONET SSA data is scarce at relatively undisturbed forest sites (northern Amazonia). Considering 129 data points in northern Amazonia, the average AERONET SSA at $637 \mathrm{~nm}$, interpolated through a power law relationship between 441 and $673 \mathrm{~nm}$, is $0.91 \pm 0.03$, whereas in the arc of deforestation 1815 data points result in an average value of $0.92 \pm 0.03$. Within the uncertainties, there is no particle SSA variability for regions in the arc of deforestation compared to relatively undisturbed regions.

Contrary to particle scattering and absorption coefficients, the Ångström exponent and the backscatter ratio did not show a clear seasonal pattern. Both parameters showed greater dispersion in the wet season, when the aerosol particle concentration was low and the instruments were operating close to its detection limit. The average Ångström exponent was $15 \%$ greater in the dry season (Table 6), which could be an echo of increased concentration of fine mode biomass burning particles from regional fires. The backscatter ratio at $550 \mathrm{~nm}$ had a median value of 0.15 , without significant differences between the wet and dry seasons (Table 6). The relationship between Ångström exponent particle size will be further discussed on Sect. 4.3.

Particle scattering and absorption coefficients showed an enhancement of approximately 50\% between 09:00 and 12:00 local time in the wet season (Fig. 9). In the wet season, sub micrometer aerosol particle number size distribution measurements (not shown) indicated an increase of $20 \%$ in the count mean diameter at the same period of the day, while the integrated particle number concentrations kept rather constant. The daytime shift of sub micrometer particle diameters towards larger sizes has also been observed in another site in Amazonia (Rissler et al., 2006), and may be attributed to the photochemical formation of secondary organic aerosols (Chen et al., 2009) in the residual layer, mixing down to the ground as the boundary layer height increases in the morning hours. A Mie modeling exercise indicated that a $20 \%$ increase on sub micrometer particle diameters may cause an increase of 50-70\% on scattering coefficients and of $10-40 \%$ on absorption coefficients. While the particle growth may be enough to explain the diurnal particle scattering enhancement during the wet season, there may be other factors, still unknown, contributing to the observed particle absorption diurnal increase. Day time emission of light absorbing biogenic particles could be a possibility. In the dry season, the regional transport of biomass burning particles seems to overwhelm the ecosystem natural aerosol dynamics, in a way that the diurnal variation of particle scattering and absorption is dominated by the boundary layer dynamics (not shown).

\subsection{Particle mass scattering and absorption coefficients}

Fine and coarse mode aerosol particle mass concentrations were obtained from the gravimetric analysis of 199 samples. The $\mathrm{PM}_{10}$ particle mass concentrations ranged between 5 and $25 \mu \mathrm{g} \mathrm{m}^{-3}$ amid February 2008 and April 2011, which is in accordance with previously reported values in a close by measurement site $\left(8-30 \mu \mathrm{g} \mathrm{m}^{-3}\right)$ (Martin et al., 2010b). Strong seasonal variations were observed in the ratio between $\mathrm{PM}_{2}$ and $\mathrm{PM}_{10}$ particle mass concentrations, as a consequence of regional fires: in the wet season $\mathrm{PM}_{2}$ accounted for $20-30 \%$ of $\mathrm{PM}_{10}$, whereas in the dry season the proportion increased to $40-80 \%$ (Fig. 10). Therefore, from wet to dry season, the aerosol population changed to a particle number size distribution pattern that is more optically active, dominated by the fine mode. This effect can be seen on mass scattering coefficients, calculated as the 

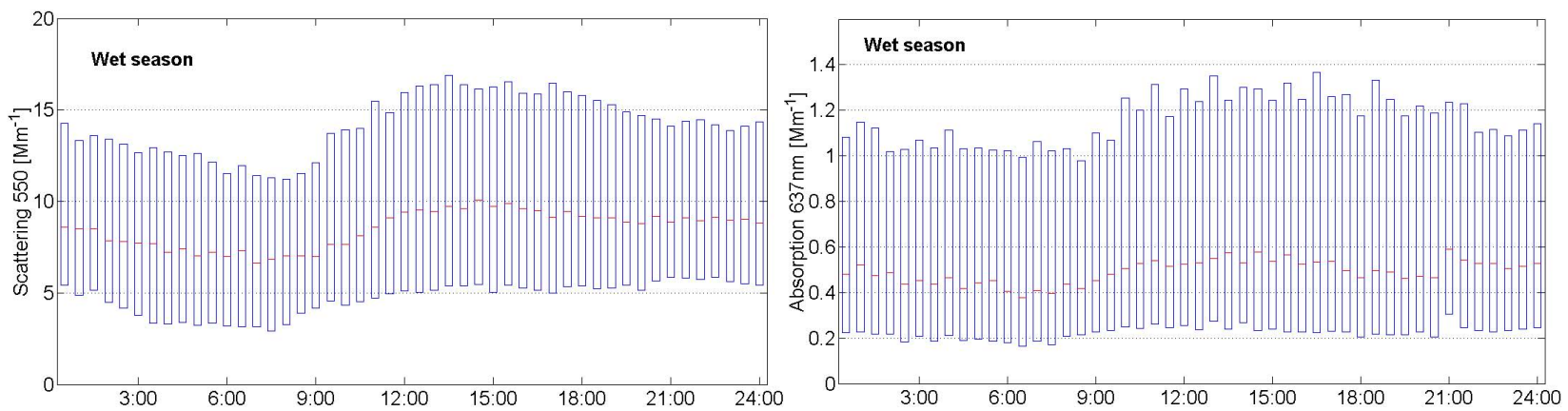

Fig. 9. Local time diurnal cycle boxplots for wet season (a) aerosol particle scattering at $550 \mathrm{~nm}$; (b) aerosol particle absorption at $637 \mathrm{~nm}$. The box lines represent the lower quartile, median, and upper quartile values.

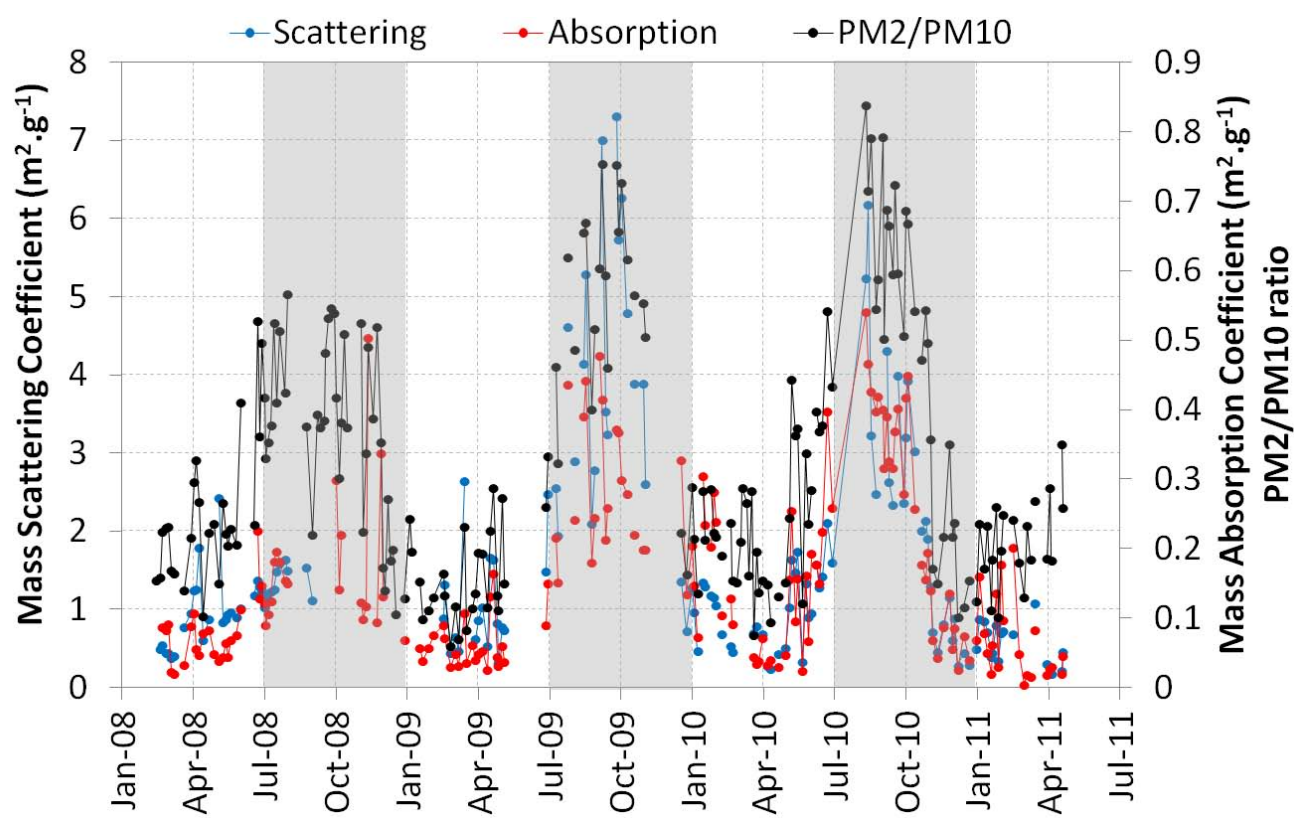

Fig. 10. Time series of particle mass scattering coefficient at $550 \mathrm{~nm}$, particle mass absorption coefficient at $637 \mathrm{~nm}$, and ratio between PM and $\mathrm{PM}_{10}$ particle mass, observed from gravimetric analysis of 199 stacked filter units samples. Shaded areas represent the dry season period.

ratio between scattering coefficients at $550 \mathrm{~nm}$ and $\mathrm{PM}_{10}$ particle mass concentration (Fig. 10). Average mass scattering coefficients increased from $0.9 \pm 0.5 \mathrm{~m}^{2} \mathrm{~g}^{-1}$ in the wet season to $2.6 \pm 1.8 \mathrm{~m}^{2} \mathrm{~g}^{-1}$ in the dry season. These values are in the range of previously reported mass scattering coefficients for dry season Amazonian aerosols $\left(2.8-5.0 \mathrm{~m}^{2} \mathrm{~g}^{-1}\right)$ (Chand et al., 2006; Hobbs et al., 1997). To our knowledge, this is the first estimation of mass scattering coefficients for the wet season Amazonian aerosols, dominated by coarse mode biogenic particles. The mass absorption coefficient also showed a similar pattern (Fig. 10), increasing from $0.09 \pm 0.07 \mathrm{~m}^{2} \mathrm{~g}^{-1}$ to $0.27 \pm 0.24 \mathrm{~m}^{2} \mathrm{~g}^{-1}$ from wet to dry season. Mass absorption coefficient for black carbon at $637 \mathrm{~nm}$ can be assumed $6.6 \mathrm{~m}^{2} \mathrm{~g}^{-1}$ as in the MAAP (Müller et al., 2011; Petzold et al., 2005), which implies that black carbon constitutes $5-10 \%$ of the $\mathrm{PM}_{10}$ particle mass concentration in the dry season and 1-2\% in the wet season.

\subsection{Relationships between scattering Ångström exponent and particle size}

In the literature, the scattering Ångström exponent has been used as an indication of particle number size distribution. Particles with diameters around $0.1 \mu \mathrm{m}$, usually associated with urban pollution and biomass burning, have a steeper spectral dependency for scattering (e.g., Schuster et al., 2006). Therefore, this parameter is expected to decrease as the aerosol particle diameter increases. Mie theory calculations performed by Collaud Coen et al. (2007) suggest that the Ångström exponent is more sensitive to particles with diameters between 0.5 and $0.8 \mu \mathrm{m}$. 


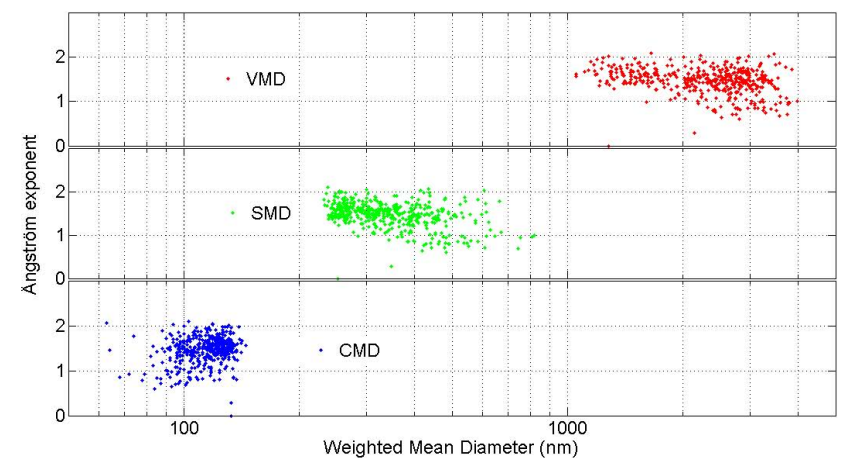

Fig. 11. Relationships between scattering Ångström exponents and three parameters calculated from sub micrometer aerosol particle number size distributions $(10-500 \mathrm{~nm})$ : count mean diameter (CMD), surface area mean diameter (SMD) and volume mean diameter (VMD). The plots comprise measurements taken between July and August 2009.

The relationships with particle size were investigated through the comparison with the following weighted mean diameters calculated from aerosol particle number size distribution measurements $(10 \mathrm{~nm}-7 \mu \mathrm{m})$ taken between July and August 2009: the count mean diameter (CMD),

$\mathrm{CMD}=\frac{\Sigma D_{P i} N_{i}}{N_{\text {total }}}$

the surface area mean diameter (SMD),

$\mathrm{SMD}=\frac{\Sigma D_{P i} S_{i}}{S_{\text {total }}}$

and the volume mean diameter (VMD),

$\mathrm{CMD}=\frac{\Sigma D_{P i} V_{i}}{V_{\text {total }}}$

where $D_{P i}, N_{i}, S_{i}$, and $V_{i}$ represents respectively particle diameter, number concentration, surface area and volume of bin $i ; N_{\text {total }}, S_{\text {total }}$, and $V_{\text {total }}$ represents the corresponding parameters integrated for the whole diameter range. Particle size distributions in the range $0.3-6 \mu \mathrm{m}$ were measured based on a physical assumption that tends to underestimate particle sizes (refer to Sect. 3.2). In this range, particle size spectra were corrected by means of optical closure study, using a Mie code to infer what size distribution would fit to the observed particle scattering and absorption coefficients (refer to Sect. 4.5).

Figure 11 shows that the correlations between Ångström exponents and weighted mean diameters are rather poor. Nevertheless, it shows that Ångström exponents decreased with SMD and VMD, as expected. The dependency of the Ångström exponent with CMD contradicted the expectations, increasing with particle size. This converse behavior has been reported for aerosols in a Chinese megacity (Garland et al., 2008) and in a boreal forest site (Virkkula et al., 2011), and might be related to the fact that surface and volume are more correlated to particle size than are number concentrations. Schuster et al. (2006) argue that for bimodal aerosol particle number size distributions the Ångström exponent can decrease with particle size, depending on the ratio of fine and coarse particle concentration. The addition of coarse mode particles with spectrally flat extinctions reduces the overall spectral variability, decreasing the Ångström exponent and damping its sensitivity to the size of fine mode particles.

\subsection{Aerosol forcing efficiency}

Daily averages of particle scattering, backscattering and absorption data were used to calculate the aerosol forcing efficiency at the top of the atmosphere, referring to the period between November 2009 and September 2010, when backscattering data was available. Figure 12 shows the histograms of aerosol forcing efficiency and cloud fraction for wet and dry season. The cloud cover was above 0.9 in $72 \%$ of the wet season days, and in $46 \%$ of the dry season days. As a consequence, the absolute value of aerosol forcing efficiency was below $-3.5 \mathrm{~W} \mathrm{~m}^{-2}$ in $70 \%$ of the wet season days and in $46 \%$ of the dry season days. Therefore, in the wet season the radiative balance is dominated by the cloud cover, or, in other words, the radiative aerosol direct effect may not be significant. In the dry season the radiative aerosol direct effect gains relevance, and can be as important as the cloud cover radiative effect, at least referring to aged biomass burning particles. That may not be true for fresh biomass burning particles (e.g., Procopio et al., 2004).

It is not appropriate to present average values for variables with this kind of distribution. However, we present statistics for the aerosol forcing efficiency (Table 7) to have means of comparison with other studies. The average values shown in Table 7 agree with the range of $24 \mathrm{~h}$ forcing efficiencies of -8 to $-20 \mathrm{~W} \mathrm{~m}^{-2}$ reported by Sena et al. (2013) and references therein for the Amazon region. Note that the median values, which are more representative when one considers the distribution of forcing efficiencies, are about 10 times lower than the values reported in the literature, which are based on remote sensing data. That is because the aerosol forcing efficiencies calculated here included days with elevated cloud fractions, which is not feasible when dealing with remote sensing data. Within the period considered here, there were only 10 days with cloud fraction less than 0.1 . Considering only those low cloud fraction days, the average forcing efficiency was $-51 \pm 10 \mathrm{~W} \mathrm{~m}^{-2}$ for the dry season. This value corresponds to 7 days in the dry season of 2010 , and is 4 times higher in magnitude than the ones reported by Sena et al. (2013) averaged along $10 \mathrm{yr}$ of remote sense observations in Amazonia. Nevertheless, it is worth to mention that the methods used for calculating the aerosol forcing efficiency from remote sense and in situ data are completely different: the former takes the forcing efficiency as the slope 
Table 7. Statistics for aerosol forcing efficiency at the top of the atmosphere calculated based on daily averages of scattering, backscatter ratio, absorption and cloud fraction (MODIS), enclosing the period between November 2009 and September 2010.

\begin{tabular}{lcccccc}
\hline & \multicolumn{5}{c}{ Aerosol Forcing Efficiency $\Delta$ F/AOD $\left[\mathrm{W} \mathrm{m}^{-2}\right.$ ] } & \\
\cline { 2 - 6 } & Average & Standard deviation & Median & 1st quartile & 3rd quartile & coverage \\
\hline All data & -9 & 15 & -0.8 & -13 & 0.0 & $65 \%$ \\
Wet season & -6 & 13 & -0.3 & -6 & 0.0 & $76 \%$ \\
Dry season & -13 & 19 & -6 & -23 & -0.2 & $55 \%$ \\
\hline
\end{tabular}

Table 8. Statistics for aerosol particle scattering coefficients ( $550 \mathrm{~nm})$, scattering Ångström exponent, absorption coefficient (637 nm), single scattering albedo $(637 \mathrm{~nm})$ and particle number concentration during episodes of influence of the Manaus urban plume between February 2008 and June 2011.

\begin{tabular}{lccccc}
\hline & Scattering $\left[\mathrm{Mm}^{-1}\right]$ & Angström & Absorption [Mm & SSA & Concentration [cm $\left.{ }^{-3}\right]$ \\
\hline median & 16.0 & 1.72 & 2.68 & 0.84 & 1502 \\
1st quartile & 12.2 & 1.41 & 1.51 & 0.78 & 1026 \\
3rd quartile & 22.3 & 2.00 & 4.96 & 0.89 & 2269 \\
Number of hours of measurements & 223 & 223 & 213 & 211 & 158 \\
affected (2008-2011) & & & & & \\
\hline
\end{tabular}

of the plot of radiative flux at the top of the atmosphere versus AOD, usually at $550 \mathrm{~nm}$, for a entire dry season data set; the latter uses daily records of spectrally averaged backscatter and single scattering albedo, without any mention to the AOD wavelength. Therefore, a forcing efficiency value calculated from in situ observations corresponds to a single data point in the curve radiative flux versus AOD, which in many cases shows a scattered linear correlation.

\subsection{Optical closure study: iterative calculation of refractive indexes}

An optical closure study was done for aerosol particle properties measured between 1 July-14 August 2009, period at which number size distribution measurements were available for particles in the optical diameter range of 10-6000 nm. Particle refractive index was calculated for each $60 \mathrm{~min}$ averaged number size distribution data, by means of matching calculated and measured particle scattering and absorption coefficients within $10 \%$. Both real and imaginary refractive indexes converged in $91 \%$ of the hourly averaged data, whenever particle scattering, absorption and number size distributions were available.

The modeled truncation error was calculated as the ratio between as the simulated integral scattering coefficient $\left(0-180^{\circ}\right)$ and the simulated Nephelometer signal considering its angular truncation $\left(7-170^{\circ}\right)$ and illumination function. In average, the model predicted $15 \pm 5 \%$ underestimation of $550 \mathrm{~nm}$ particle scattering coefficients due to the nephelometer angular truncation. This value is compatible with the correction factor calculated based on Anderson and Ogren (1998) (refer to Sect. 2.2). The modeled truncation correction factor varied between $8 \%$ and $35 \%$ at 550nm. Correc- tion factors above $30 \%$ were obtained when the measured scattering coefficient at $550 \mathrm{~nm}$ was below $15 \mathrm{Mm}^{-1}$.

The average refractive index and standard deviation resulting from the optical closure study was (1.47 \pm 0.07$)$ $(0.008 \pm 0.005) \mathrm{i}$, corresponding to effective values for aerosol particles in an Amazonian primary forest site in the dry season. The average particle refractive index obtained here is compatible with other estimative reported for Amazonia. Dubovik et al. (2002) report averages of 1.47-0.00093i for the Amazon forest, retrieved from worldwide AERONET network of ground-based radiometers. Guyon et al. (2003) report averages of 1.42-0.006i for background aerosols and of 1.41-0.013i for biomass burning aerosol particles at a pasture site in Amazonia, under ambient RH conditions, by using a similar procedure of closure between measured and calculated particle optical properties. Schkolnik et al. (2007) obtained $1.87-0.22 \mathrm{i}$ for elemental carbon aerosols and 1.3 for organic aerosol, based on measurements of aerosol optical properties and chemical composition in an Amazonian pasture site during the dry season.

The closure between calculated and measured particle optical properties was not found in $9 \%$ of the data for a variety of reasons: calculated scattering and absorption converged for different refractive indexes; particle volume concentration was not adequate to reach the measured scattering coefficient; or calculated absorption coefficient suffered a sudden increase as a function of the imaginary refractive index without convergence to measured values. This abrupt increase on calculated particle absorption occurred when measured absorption coefficients were in order of $0.1 \mathrm{Mm}^{-1}$. Improving the imaginary refractive index resolution from 0.0005 to $0.0001 \mathrm{did}$ not help to increase the percentage of achieved 

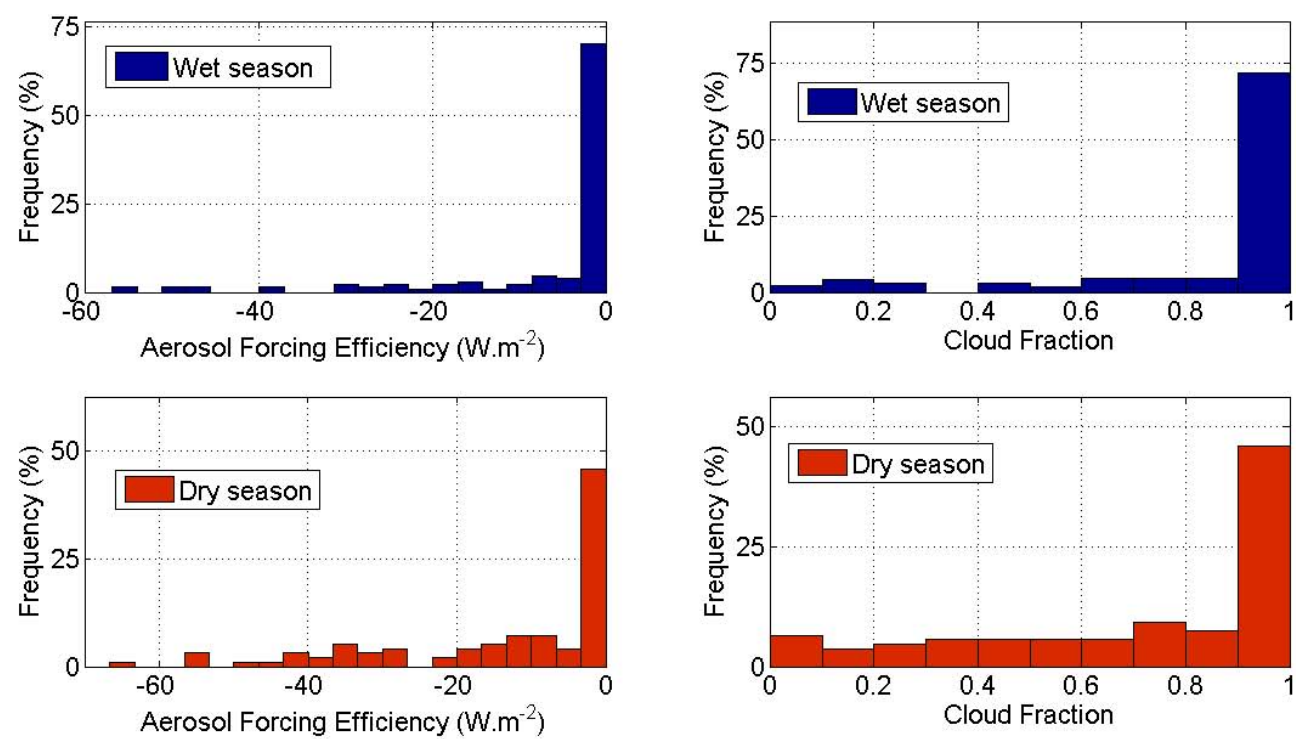

Fig. 12. Frequency histograms for the aerosol forcing efficiency and for the cloud fraction during wet and dry seasons, comprising the period between November 2009 and September 2010.

closure between measured and modeled data. To verify the accuracy of the calculated refractive index, a sensitivity test was performed, using as input to the Mie code particle size distributions, scattering and absorption coefficients within the instrument error estimates mentioned in Sect. 2.2. The sensitivity test indicated variations of $4 \%$ on the real part of the refractive index, and of $15 \%$ on its imaginary part, in average.

Adding to the measurements uncertainties, there are errors related to the assumption of homogeneous internal mixture and sphericity throughout the whole measured size spectrum $(10-7000 \mathrm{~nm})$. The assumption of homogeneous spherical aerosols is a crude simplification for the variety of shapes and mixing states of atmospheric aerosol particles, especially when coarse mode particles are included. Several studies report the effects of non sphericity and different mixing states on aerosol optical properties (e.g. Cheng et al., 2006; Wagner et al., 2011; Ma et al., 2011), and this will be the focus of another paper. Therefore, we emphasize that the values obtained for the refractive index must be interpreted as an effective refractive index for the whole aerosol population.

To examine the scattering and absorption efficiency as a function of particle size, Mie model runs were performed using as input the previously converged refractive indexes. Each particle number size distribution starting at $10 \mathrm{~nm}$ was truncated at different particle diameters, comprising 13 particle size ranges $(10-56 ; 10-115 ; 10-200 ; 10-300 ; 10-400$; $10-500 ; 10-600 ; 10-750 ; 10-900 ; 10-1500 ; 10-2500 ; 10-$ $4000 ; 10-6000 \mathrm{~nm})$. The cumulative contribution of each particle size range to the scattering and absorption coefficients calculated for the entire size range $(10-6000 \mathrm{~nm})$ is shown in Fig. 13. In average, particles with diameters be- tween 10 and $500 \mathrm{~nm}$ accounted for $77 \%$ of the scattering coefficient calculated for the entire size range. According to the model results, super micrometer particles contributed $50 \%$ to the calculated absorption coefficients. This finding is associated with the assumption of size independent refractive indexes, and contradicts the expectative of decreasing absorption efficiency for particles larger than about $300 \mathrm{~nm}$ in diameter (Bond and Bergstrom, 2006). Nevertheless, the literature has shown evidences of the presence of light absorbing particles in the coarse mode. These particles are most likely of biogenic origin, since typical aerosol organic fractions in Amazonia range between 70 and $85 \%$, while soil dust particles comprise only $10-15 \%$ of coarse particle mass concentration (Martin, et al., 2010b). Light absorbing carbonaceous aerosols of biogenic origin result from processes like oxidation of biogenic materials and polymerization, and are often denominated "brown carbon" (Andreae and Gelencsér, 2006; Andreae and Crutzen, 1997). Occurrence of external and internal mixing instead of the assumed homogeneous spherical aerosols might also have contributed to the increased importance of larger particles to the calculated absorption coefficients. Internal mixtures in the form of an absorbing core surrounded by a less absorbing shell increasing the absorption efficiency by a factor of 2-3 (Martins et al., 1998).

\subsection{Influence of external sources over aerosol optical properties}

\subsubsection{Manaus urban plume influence}

Between 2008 and 2011, 43 periods of influence of the Manaus urban plume over the measurement site were detected, comprising $1.5 \%$ of the dataset. Episodes occurred with local 
Table 9. Statistics for aerosol particle scattering coefficients ( $550 \mathrm{~nm})$, scattering Ångström exponent, absorption coefficient (637 nm), single scattering albedo $(637 \mathrm{~nm})$ and particle number concentration during episodes of African advection between Feb and May 2008.

\begin{tabular}{lccccc}
\hline & Scattering $\left[\mathrm{Mm}^{-1}\right]$ & Ångström & Absorption $\left[\mathrm{Mm}^{-1}\right]$ & SSA & Concentration [cm $\left.{ }^{-3}\right]$ \\
\hline median & 6.2 & 1.29 & 0.95 & 0.82 & 352 \\
1st quartile & 3.3 & 0.88 & 0.38 & 0.77 & 300 \\
3rd quartile & 12.0 & 1.50 & 1.46 & 0.94 & 488 \\
Number of hours of measurements & 254 & 254 & 240 & 230 & 202 \\
affected in 2008 & & & & \\
\hline
\end{tabular}

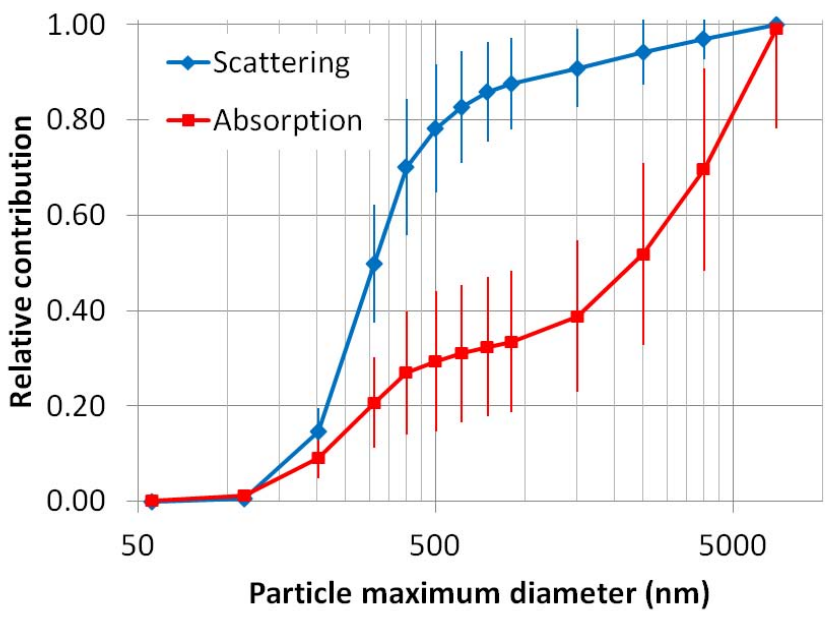

Fig. 13. Cumulative contribution of 13 particle size ranges to scattering $(550 \mathrm{~nm})$ and absorption $(637 \mathrm{~nm})$ coefficients calculated using a Mie model. Error bars represent standard deviations.

winds ranging between 120 and $190^{\circ}$, and were characterized by a consistent increase on aerosol number concentrations, scattering and absorption coefficients. HYSPLIT backtrajectories were calculated for each episode, to derive the plume age and the number of trajectory points over the Manaus area (a square between the coordinates $2.95^{\circ} \mathrm{S} ; 3.15^{\circ} \mathrm{S}$; $59.85^{\circ} \mathrm{W} ; 60.15^{\circ} \mathrm{W}$ ). The plume age reaching the research site ranged between 5 and $24 \mathrm{~h}$, and the trajectories enclosed 1 to 15 points (out of 24) inside the Manaus area. There was not a clear relationship between aerosol properties and the age of the urban plume.

Table 8 shows statistics for aerosol particle properties measured during episodes of Manaus urban plume influence. Median particle scattering coefficients were 2.5 times greater than the ones measured at clean conditions during the wet season. Median particle absorption coefficients increased by a factor of 5 from samples taken under clean conditions to samples taken under the influence of the urban plume. Accordingly, the particle SSA decreased by $5 \%$.

Figure 14 shows an example of the Manaus plume effect over aerosol measurements at the forest reserve. Six air trajectories passing over the Manaus area reached the site between 04:00 and 09:00 local time of 25 April 2009. No precipitation occurred on this day. Under the influence of the urban plume, particle scattering coefficients increased by a factor of 1.7, absorption coefficients increased from 2 to $18 \mathrm{Mm}^{-1}$, particle number concentrations increased from 400 to $3300 \mathrm{~cm}^{-3}$, and particle SSA values decreased from 0.93 to 0.75 . After 09:00 local time, northeast winds predominated, bringing clean air and restoring the wet season typical particle number and mass concentrations.

\subsubsection{Influence of African advection}

Recent works reported the transport of African aerosols to the research site in the wet season of 2008 (e.g., Baars et al., 2011; Ben-Ami et al., 2010). The phenomenon might have occurred also in 2009 and 2010, but here only the well documented episodes occurred in 2008 (Table 4) will be used to calculate statistics for aerosol particle properties during the periods of influence of African aerosol advection. Table 9 shows that median particle absorption coefficients increased by factor of 2 when compared to the overall wet season statistics (Table 6). As a matter of comparison, Müller et al. (2009) report particle absorption coefficients ranging from 0.1 to $10 \mathrm{Mm}^{-1}$ for Saharan mineral dust in southern Morocco. Particle scattering coefficients were not significantly affected by the advection of African aerosols, so that the SSA median values decreased by $7 \%$ in comparison to the wet season values. The elevated number of hours of influence on particle measurements ( $240 \mathrm{~h}$ in 4 months) attests the significance of this external source over Amazonian aerosol particle properties, especially during the wet season.

\section{Conclusions}

Two major classes of aerosol particles, with significantly different optical properties were identified in a primary forest site in Amazonia: coarse mode predominant biogenic aerosols in the wet season (January-June), naturally released by the forest metabolism, and fine mode dominated biomass burning aerosols in the dry season (July-December), transported from regional fires. From wet to dry season, median aerosol particle scattering $(550 \mathrm{~nm})$ and absorption $(637 \mathrm{~nm})$ coefficients increased from $6.3 \mathrm{Mm}^{-1}$ to $22 \mathrm{Mm}^{-1}$, and from $0.5 \mathrm{Mm}^{-1}$ to $2.8 \mathrm{Mm}^{-1}$, respectively. The observation of 

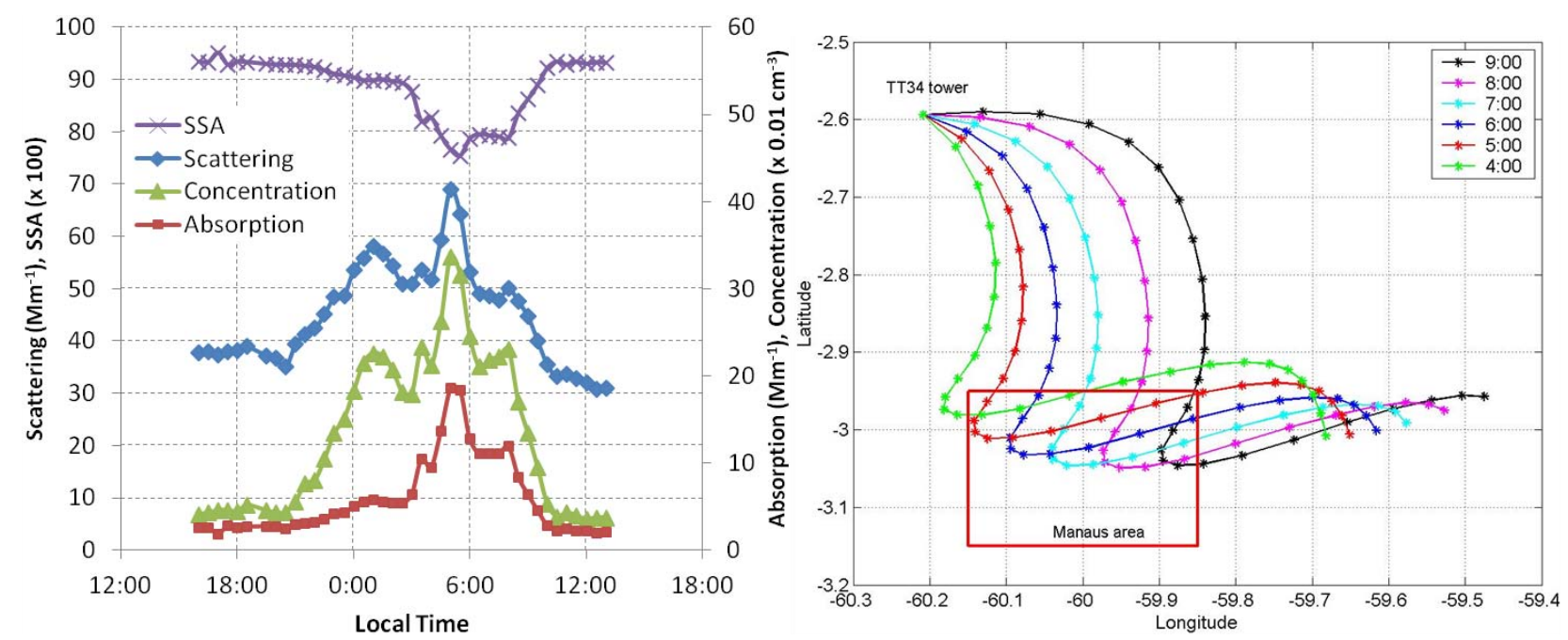

Fig. 14. Example of Manaus urban plume entrance in the research site on 25 April 2009. (a) Evolution of particle single scattering albedo - SSA $(637 \mathrm{~nm})$, scattering coefficient $(550 \mathrm{~nm})$, absorption coefficient $(637 \mathrm{~nm})$ and number concentration; (b) HYSPLIT back-trajectories reaching the measurement site at the time specified (local time). Each trajectory point represents one hour less from the start time.

relevant particle absorption coefficients during periods of pristine atmospheric conditions in the wet season indicate that some of the Amazonian biogenic particles are light absorbers, as was also stated by Guyon et al. (2004).

While particle scattering and absorption presented high seasonality, the derived aerosol intrinsic properties, namely, the Ångström exponent for scattering, the backscatter ratio and the single scattering albedo, did not show a clear seasonal cycle. The median value for the dry particle SSA at $637 \mathrm{~nm}$ was 0.88 equally in the dry and in the wet season. The weak seasonal variation of SSA, in spite of the increased concentrations of light absorbing biomass burning particles in the dry season, can be in part explained by the fact that both particle scattering and absorption increased by similar rates in the dry season. Although the scattering increase may be surprising at first, evidences show that biomass burning smoke plumes can contain particles with a variety of ratios between scattering and absorption coefficients, depending on fire stage (smoldering or flaming), on plume age, and on the atmospheric processes the plume has been trough (for example, in-cloud processing) (Reid et al., 2005).

In the dry season, the particle scattering coefficients increased both as a consequence of decreased precipitation rates (from 10 in the wet season to $4 \mathrm{~mm} \mathrm{day}^{-1}$ in the dry season, in average), and of enhanced fine particle number and mass concentrations in the dry season (fine mode particle mass corresponded to $40-80 \%$ of $\mathrm{PM}_{10}$ ). Fine mode particles are more efficient to scatter light in comparison to the coarse mode dominated biogenic particles in the wet season. Accordingly, mass scattering coefficients at $550 \mathrm{~nm}$ increased from $0.9 \pm 0.5$ to $2.6 \pm 1.8 \mathrm{~g} \mathrm{~m}^{-2}$ from wet to dry season. The corresponding increase on mass absorption coefficients at $637 \mathrm{~nm}$ was $0.09 \pm 0.07$ to $0.27 \pm 0.24 \mathrm{~g} \mathrm{~m}^{-2}$.
Assuming a mass absorption coefficient for black carbon of $6.6 \mathrm{~m}^{2} \mathrm{~g}^{-1}$ (Petzold et al., 2005), we estimate that black carbon constitutes $5-10 \%$ of the $\mathrm{PM}_{10}$ particle mass concentration in the dry season. The remaining absorption could be attributed to either light absorbing carbonaceous particles from biomass burning fires, often denominated "brown carbon" (Andreae and Gelencsér, 2006), and to mineral dust, which typically constitutes a minor fraction of $\mathrm{PM}_{10}$ Amazonian aerosol (8\%, as reported by Rizzo et al., 2010).

By means of a closure study between optical particle properties and number size distribution measurements, an effective particle refractive index of $(1.47 \pm 0.07)-$ $(0.008 \pm 0.005)$ i was retrieved, corresponding to aerosol particles in an Amazonian primary forest site in the dry season. The same closure study indicated that, in average, particles with diameters between 10 and $500 \mathrm{~nm}$ accounted for $77 \%$ of the scattering coefficient calculated for the entire size range $(10 \mathrm{~nm}-7 \mu \mathrm{m})$. In the closure study internally mixed homogeneous spheres were assumed. Further information could be achieved by modeling the optical response of particles with different degrees of mixture and chemical composition.

Optical particle properties measured above the canopy were used to estimate the aerosol forcing efficiency at the top of the atmosphere. Results indicated that at this primary forest site the radiative balance was dominated by cloud cover, particularly in the wet season. Due to the high cloud fractions, the absolute value of the aerosol forcing efficiency was below $-3.5 \mathrm{~W} \mathrm{~m}^{-2}$ in $70 \%$ of the wet season days and in $46 \%$ of the dry season days. These values are lower than the ones reported in the literature, which are based on remote sensing data. That is because the aerosol forcing efficiencies calculated here included days with elevated cloud fractions, which is not feasible when dealing with remote sensing data. 
Besides the seasonal variation, the influence of external aerosol sources was observed occasionally. Between 2008 and 2011, 43 periods of influence of the Manaus urban plume were identified, comprising $1.5 \%$ of the dataset. The events were characterized by a consistent increase on particle scattering (factor 2.5) and on absorption coefficients (factor 5), lasting from $4 \mathrm{~h}$ to a whole day. Advection of biomass burning and mineral dust particles from Africa affected $240 \mathrm{~h}$ of measurements between February and May 2008 (8\% of the corresponding dataset). The events lasted from 1 to 7 days, showing median particle absorption coefficients increased by factor of 2, and median SSA values decreased by $7 \%$, in comparison to wet season conditions.

\section{Supplementary material related to this article is available online at: http://www.atmos-chem-phys.net/13/ 2391/2013/acp-13-2391-2013-supplement.pdf.}

Acknowledgements. This work was supported by Fundação de Amparo à Pesquisa do Estado de São Paulo (FAPESP - AEROCLIMA 08/58100-2), Conselho Nacional de Desenvolvimento Científico (CNPq) and European Integrated FP6 project on Aerosol Cloud Climate and Air Quality Interactions (EUCAARI - 34684), under the scope of LBA experiment. We thank INPA (Instituto Nacional de Pesquisas da Amazônia) for the coordination work of the LBA Experiment. We thank Ya Fang Cheng for providing a Mie code. We thank several key persons for the support on aerosol sampling and analysis: Alcides Ribeiro, Ana Lucia Loureiro, Fernando Morais, Fábio Jorge and Lívia Oliveira.

Edited by: V.-M. Kerminen

\section{References}

Anderson, T. L., Covert, D. S., Marshall, S. F., Laucks, M. L., Charlson, R. J., Waggoner, A. P., Ogren, J. A., Caldow, R., Holm, R. L., Quant, F. R., Sem, G. J., Wiedensohler, A., Ahlquist, N. A., and Bates, T. S.: Performance characteristics of a high-sensitivity, three-wavelength, total scatter/backscatter nephelometer, Am. Meteorol. Soc., 13, 967-986, 1996.

Anderson, T. L. and Ogren, J. A.: Determining Aerosol Radiative Properties Using the TSI 3563 Integrating Nephelometer, Aerosol Sci. Technol., 29, 57-69, doi:10.1080/02786829808965551, 1998.

Anderson, T. L., Covert, D. S., Wheeler, J. D., Harris, J., Perry, K. D., Trost, B. E., Jaffe, D. J., and Ogren, J. A.: Aerosol backscatter fraction and single scattering albedo: Measured values and uncertainties at a coastal station in the Pacific Northwest, J. Geophys. Res., 104, 26793-26807, 1999.

Anderson, T. L., Masonis, S. J., Covert, D. S., Ahlquist, N. C., Howell, S. G., Clarke, A. D., and Mcnaughton, C. S.: Variability of aerosol optical properties derived from in situ aircraft measurements during ACE-Asia, J. Geophys. Res., 108, 8647, doi:10.1029/2002JD003247, 2003.
Andreae, M. O.: Correlation between cloud condensation nuclei concentration and aerosol optical thickness in remote and polluted regions, Atmos. Chem. Phys., 9, 543-556, doi:10.5194/acp-9-543-2009, 2009.

Andreae, M. O. and Crutzen, P. J.: Atmospheric Aerosols: Biogeochemical Sources and Role in Atmospheric Chemistry, Science, 276, 1052, doi:10.1126/science.276.5315.1052, 1997.

Andreae, M. O. and Gelencsér, A.: Black carbon or brown carbon? The nature of light-absorbing carbonaceous aerosols, Atmos. Chem. Phys., 6, 3131-3148, doi:10.5194/acp-6-3131-2006, 2006.

Andreae, M. O., Rosenfeld, D., Artaxo, P., Costa, A. A., Frank, G. P., Longo, K. M., and Silva-Dias, M. A. F.: Smoking Rain Clouds over the Amazon, Science, 303, 1337-1342, doi:10.1126/science.1092779, 2004.

Andrews, E., Sheridan, P. J., Fiebig, M., McComiskey, A., Ogren, J. a., Arnott, P., Covert, D., Elleman, R., Gasparini, R., Collins, D., Jonsson, H., Schmid, B. and Wang, J.: Comparison of methods for deriving aerosol asymmetry parameter, J. Geophys. Res., 111, 1-16, doi:10.1029/2004JD005734, 2006.

Ångstrom, A.: On the Atmospheric Transmission of Sun Radiation and on Dust in the Air, Geograf. Ann., 11, 156-166, 1929.

Ansmann, A., Baars, H., Tesche, M., Müller, D., Althausen, D., Engelmann, R., Pauliquevis, T. and Artaxo, P.: Dust and smoke transport from Africa to South America: Lidar profiling over Cape Verde and the Amazon rainforest, Geophys. Res. Lett., 36, 2-6, doi:10.1029/2009GL037923, 2009.

Araújo, A. C., Nobre, A. D., Kruijt, B., Elbers, J. A., Dallarosa, R., Stefani, P., von Randow, C., Manzi, A. O., Culf, A. D., Gash, J. H. C., Valentini, R., and Kabat, P: Comparative measurements of carbon dioxide fluxes from two nearby towers in a central Amazonian rainforest: The Manaus LBA site, J. Geophys. Res., 107, 1-20, doi:10.1029/2001JD000676, 2002.

Artaxo, P. and Hansson, H.-C.: Size Distribution of Biogenic Aerosol Particles, Atmos. Environ., 29, 393-402, 1995.

Artaxo, P., Gerab, F., Yamasoe, M. A., and Martins, J. V: Fine mode aerosol composition at three long-term atmospheric monitoring sites in the Amazon Basin, J. Geophys. Res., 99, 22857-22868, 1994.

Artaxo, P., Martins, J. V., Yamasoe, M. A., Procópio, A. S., Pauliquevis, T. M., Andreae, M. O., Guyon, P., Gatti, L. V., and Cordova, A. M. L.: Physical and chemical properties of aerosols in the wet and dry seasons in Rondônia, Amazonia, J. Geophys. Res., 107, 8081, doi:10.1029/2001JD000666, 2002.

Baars, H., Ansmann, A., Althausen, D., Engelmann, R., Artaxo, P., Pauliquevis, T., and Souza, R.: Further evidence for significant smoke transport from Africa to Amazonia, Geophys. Res. Lett., 38, 1-6, doi:10.1029/2011GL049200, 2011.

Baars, H., Ansmann, A., Althausen, D., Engelmann, R., Heese, B., Müller, D., Artaxo, P., Paixao, M., Pauliquevis, T., and Souza, R.: Aerosol profiling with lidar in the Amazon Basin during the wet and dry season, J. Geophys. Res., 117, 1-16, D21201, doi:10.1029/2012JD018338, 2012.

Ben-Ami, Y., Koren, I., Rudich, Y., Artaxo, P., Martin, S. T., and Andreae, M. O.: Transport of North African dust from the Bodélé depression to the Amazon Basin: a case study, Atmos. Chem. Phys., 10, 7533-7544, doi:10.5194/acp-10-7533-2010, 2010.

Bohren, C. F. and Huffman, D. R.: Absorption and scattering of light by small particles, Wiley-Vch, Mörlenbach, Germany, 
2008.

Bond, T. and Bergstrom, R.: Light Absorption by Carbonaceous Particles: An Investigative Review, Aerosol Sci. Technol., 40, 27-67, doi:10.1080/02786820500421521, 2006.

Capes, G., Johnson, B., Mcfiggans, G., Williams, P. I., Haywood, J., and Coe, H.: Aging of biomass burning aerosols over West Africa: Aircraft measurements of chemical composition, microphysical properties, and emission ratios, J. Geophys. Res., 113, 1-13, D00C15, doi:10.1029/2008JD009845, 2008.

Chand, D., Guyon, P., Artaxo, P., Schmid, O., Frank, G. P., Rizzo, L. V., Mayol-Bracero, O. L., Gatti, L. V., and Andreae, M. O.: Optical and physical properties of aerosols in the boundary layer and free troposphere over the Amazon Basin during the biomass burning season, Atmos. Chem. Phys., 6, 2911-2925, doi:10.5194/acp-6-2911-2006, 2006.

Chen, Q., Farmer, D. K., Schneider, J., Zorn, S. R., Heald, C. L., Karl, T. G., Guenther, A., Allan, J. D., Robinson, N., Coe, H., Kimmel, J. R., Pauliquevis, T., Borrmann, S., Pöschl, U., Andreae, M. O., Artaxo, P., Jimenez, J. L., Martin, S. T.: Mass spectral characterization of submicron biogenic organic particles in the Amazon Basin, Geophys. Res. Lett., 36, 1-5, L20806, doi:10.1029/2009GL039880, 2009.

Cheng, Y. F., Eichler, H., Wiedensohler, A., Heintzenberg, J., Zhang, Y. H., Hu, M., Herrmann, H., Zeng, L. M., Liu, S., Gnauk, T., Brüggemann, E., and He, L. Y.: Mixing state of elemental carbon and non-light-absorbing aerosol components derived from in situ particle optical properties at Xinken in Pearl River Delta of China, J. Geophys. Res., 111, 1-18, doi:10.1029/2005JD006929, 2006.

Cheng, Y. F., Wiedensohler, A., Eichler, H., Heintzenberg, J., Tesche, M., Ansmann, A., Wendisch, M., Su, H., Althausen, D., and Herrmann, H.: Relative humidity dependence of aerosol optical properties and direct radiative forcing in the surface boundary layer at Xinken in Pearl River Delta of China: An observation based numerical study, Atmos. Environ., 42, 6373-6397, doi:10.1016/j.atmosenv.2008.04.009, 2008.

Collaud Coen, M., Weingartner, E., Nyeki, S., Cozic, J., Henning, S., Verheggen, B., Gehrig, R., and Baltensperger, U.: Long-term trend analysis of aerosol variables at the highalpine site Jungfraujoch, J. Geophys. Res., 112, D13213, doi:10.1029/2006JD007995, 2007.

Davidson, E. A., Artaxo, P., Balch, J. K., Brown, I. F., Bustamante, M. M. C., Arau, A. C. De, Coe, M. T., Defries, R. S., Keller, M., Longo, M., Munger, J. W., Schroeder, W., Soares-Filho, B. S., Souza Jr., C. M., and Wofsy, S. C.: The Amazon basin in transition, Nature, 481, 321-328, doi:10.1038/nature10717, 2012.

Doherty, S. J., Quinn, P. K., Jefferson, A., Carrico, C. M., Anderson, T. L., and Hegg, D.: A comparison and summary of aerosol optical properties as observed in situ from aircraft, ship, and land during ACE-Asia, J. Geophys. Res., 110, D04201, doi:10.1029/2004JD004964, 2005.

Draxler, R. R. and Rolph, G.: HYbrid Single-Particle Lagrangian Integrated Trajectory) Model access via NOAA ARL READY Website, HYSPLIT (HYbrid Single-Particle Lagrangian Integrated Trajectory) Model access via NOAA ARL READY Website, available online from: http://ready.arl.noaa.gov/HYSPLIT. php, 2012.

Dubovik, O., Holben, B., Eck, T. F., Smirnov, A., Kaufman, Y. J., King, M. D., Tanré, D. and Slutsker, I.: Variability of Absorp- tion and Optical Properties of Key Aerosol Types Observed in Worldwide Locations, Journal of the Atmospheric Sciences, 59, 590-608, doi:10.1175/1520-0469(2002), 2002.

Fan, J., Zhang, R., Tao, W.-K., and Mohr, K. I.: Effects of aerosol optical properties on deep convective clouds and radiative forcing, J. Geophys. Res., 113, 1-16, doi:10.1029/2007JD009257, 2008.

Forster, P., Ramaswamy, V., Artaxo, P., Berntsen, T., Betts, R., Fahey, D. W., Haywood, J., Lean, J., Lowe, D. C., Myhre, G., Nganga, J., Prinn, R., Raga, G., Schulz, M., Van Dorland, R., Bodeker, G., Boucher, O., Collins, W. D., Conway, T. J., Dlugokencky, E., Elkins, J. W., Etheridge, D., Foukal, P., Fraser, P., Geller, M., Joos, F., Keeling, C. D., Kinne, S., Lassey, K., Lohmann, U., Manning, A. C., Montzka, S., Oram, D., O'Shaughnessy, K., Piper, S., Plattner, G.-K., Ponater, M., Ramankutty, N., Reid, G., Rind, D., Rosenlof, K., Sausen, R., Schwarzkopf, D., Solanki, S. K., Stenchikov, G., Stuber, N., Takemura, T., Textor, C., Wang, R., Weiss, R. and Whorf, T.: Changes in atmospheric constituents and in radiative forcing. Climate Change 2007: The Physical Science Basis, edited by: Solomon, S., Qin, D., Manning, M., Chen, Z., Marquis, M., Averyt, K. B., Tignor, M., and Miller, H. L., Cambridge University Press, Cambridge, UK and New York, USA, 2007.

Garland, R. M., Yang, H., Schmid, O., Rose, D., Nowak, A., Achtert, P., Wiedensohler, A., Takegawa, N., Kita, K., Miyazaki, Y., Kondo, Y., Hu, M., Shao, M., Zeng, L. M., Zhang, Y. H., Andreae, M. O., and Pöschl, U.: Aerosol optical properties in a rural environment near the mega-city Guangzhou, China: implications for regional air pollution, radiative forcing and remote sensing, Atmos. Chem. Phys., 8, 5161-5186, doi:10.5194/acp-85161-2008, 2008.

Guyon, P., Boucher, O., Graham, B., Beck, J., Mayol-bracero, O. L., Roberts, G. C., Maenhaut, W., Artaxo, P., and Andreae, M. O.: Refractive index of aerosol particles over the Amazon tropical forest during LBA-EUSTACH 1999, J. Aerosol Sci., 34, 883907, doi:10.1016/S0021-8502(03)00052-1, 2003.

Guyon, P., Graham, B., Roberts, G. C., Mayol-bracero, O. L., Maenhaut, W., Artaxo, P., and Andreae, M. O.: Sources of optically active aerosol particles over the Amazon forest, Atmos. Environ., 38, 1039-1051, doi:10.1029/2003JD003465, 2004.

Haerter, J. O., Roeckner, E., Tomassini, L., and von Storch, J.-S.: Parametric uncertainty effects on aerosol radiative forcing, Geophys. Res. Lett., 36, 1-5, doi:10.1029/2009GL039050, 2009.

Hand, J. L. and Kreidenweis, S. M.: A New Method for Retrieving Particle Refractive Index and Effective Density from Aerosol Size Distribution Data A New Method for Retrieving Particle Refractive Index and Effective Density from Aerosol Size Distribution Data, Aerosol Sci. Technol., 36, 1012-1026, doi:10.1080/0278682029009227, 2002.

Hansen, J., Sato, M., and Ruedy, R.: Radiative forcing and climate response, J. Geophys. Res., 102, 6831-6864, 1997.

Haywood, J. M. and Shine, K. P.: The effect of anthropogenic sulfate and soot aerosol on the clear sky planetary radiation budget, Geophys. Res. Lett., 22, 603-606, 1995.

Heim, M., Mullins, B., Umhauer, H. and Kasper, G.: Performance evaluation of three optical particle counters with an efficient "multimodal" calibration method, J. Aerosol Sci., 39, 10191031, doi:10.1016/j.jaerosci.2008.07.006, 2008. 
Hinds, W. C.: Aerosol Technology, Wiley-Interscience, New York, USA, 1999.

Hobbs, P. V., Reid, J. S., Kotchenruther, R. A., Ferek, R. J., and Weiss, R.: Direct Radiative Forcing by Smoke from Biomass Burning, Science, 275(5307), 1777-1778, doi:10.1126/science.275.5307.1777, 1997.

Holben, B. N., Eck, T. F., Slutsker, I., Smirnov, A., Sinyuk, A., Schafer, J., Giles, D., and Dubovik, O.: Aeronet's Version 2.0 quality assurance criteria, available online from: http://aeronet. gsfc.nasa.gov/new_web/PDF/AERONETcriteria_final1.pdf, 2006.

Hudson, J. G. and Yum, S. S.: Cloud condensation nuclei spectra and polluted and clean clouds over the Indian Ocean, J. Geophys. Res., 107, 8022, doi:10.1029/2001JD000829, 2002.

Hulstrom, R., Bird, R., and Riordan, C.: Spectral solar irradiance data sets for selected terrestrial conditions, Sol. Cells, 15, 365391,1985

IBGE: Estimativa Populacional - Instituto Brasileiro de Geografia e Estatística, available online from: www.ibge.gov.br/home/ estatistica/populacao/estimativa2011, 2011.

Kaufman, Y., Hobbs, P., Kirchhoff, V., Artaxo, P., Remer, L. A., Holben, B. N., King, M. D., Ward, D. E., Prins, E. M., Longo, K. M., Mattos, L. F., Nobre, C. A., Spinhirne, J. D., Ji, Q., Thompson, A. M., Gleason, J. F., Christopher, S. A., and Tsay, S. C.: Smoke, clouds, and radiation-Brazil (SCAR-B) experiment, J. Geophys. Res., 103, 31783-31808, 1998.

Kaufman, Y. J., Koren, I., Remer, L. A., Tanré, D., Ginoux, P., and Fan, S.: Dust transport and deposition observed from the Terra-Moderate Resolution Imaging Spectroradiometer (MODIS) spacecraft over the Atlantic Ocean, J. Geophys. Res., 110, 1-16, doi:10.1029/2003JD004436, 2005.

Komppula, M., Lihavainen, H., Kerminen, V. M., Kulmala, M., and Viisanen, Y.: Measurements of cloud droplet activation of aerosol particles at a clean subarctic background site, J. Geophys. Res., 110, D06204, doi:10.1029/2004JD005200, 2005.

Koren, I., Kaufman, Y. J., Remer, L. A., and Martins, J. V.: Measurement of the Effect of Amazon Smoke on Inhibition of Cloud Formation, Science, 303, 1342, doi:10.1126/science.1089424, 2004.

Kotchenruther, R. A. and Hobbs, P. V: Humidification factors of aerosols from biomass burning in Brazil, J. Geophys. Res., 103, 32081-32089, 1998.

Kulmala, M., Asmi, A., Lappalainen, H. K., Baltensperger, U., Brenguier, J.-L., Facchini, M. C., Hansson, H.-C., Hov, Ø., O'Dowd, C. D., Pöschl, U., Wiedensohler, A., Boers, R., Boucher, O., de Leeuw, G., Denier van der Gon, H. A. C., Feichter, J., Krejci, R., Laj, P., Lihavainen, H., Lohmann, U., McFiggans, G., Mentel, T., Pilinis, C., Riipinen, I., Schulz, M., Stohl, A., Swietlicki, E., Vignati, E., Alves, C., Amann, M., Ammann, M., Arabas, S., Artaxo, P., Baars, H., Beddows, D. C. S., Bergström, R., Beukes, J. P., Bilde, M., Burkhart, J. F., Canonaco, F., Clegg, S. L., Coe, H., Crumeyrolle, S., D'Anna, B., Decesari, S., Gilardoni, S., Fischer, M., Fjaeraa, A. M., Fountoukis, C., George, C., Gomes, L., Halloran, P., Hamburger, T., Harrison, R. M., Herrmann, H., Hoffmann, T., Hoose, C., Hu, M., Hyvärinen, A., Hõrrak, U., Inuma, Y., Iversen, T., Josipovic, M., Kanakidou, M., Kiendler-Scharr, A., Kirkevåg, A., Kiss, G., Klimont, Z., Kolmonen, P., Komppula, M., Kristjánsson, J.-E., Laakso, L., Laaksonen, A., Labonnote, L., Lanz, V. A., Lehtinen, K. E. J., Rizzo, L. V., Makkonen, R., Manninen, H. E., McMeek- ing, G., Merikanto, J., Minikin, A., Mirme, S., Morgan, W. T., Nemitz, E., O’Donnell, D., Panwar, T. S., Pawlowska, H., Petzold, A., Pienaar, J. J., Pio, C., Plass-Duelmer, C., Prévôt, A. S. H., Pryor, S., Reddington, C. L., Roberts, G., Rosenfeld, D., Schwarz, J., Seland, Ø., Sellegri, K., Shen, X. J., Shiraiwa, M., Siebert, H., Sierau, B., Simpson, D., Sun, J. Y., Topping, D., Tunved, P., Vaattovaara, P., Vakkari, V., Veefkind, J. P., Visschedijk, A., Vuollekoski, H., Vuolo, R., Wehner, B., Wildt, J., Woodward, S., Worsnop, D. R., van Zadelhoff, G.-J., Zardini, A. A., Zhang, K., van Zyl, P. G., Kerminen, V.-M., Carslaw, K., and Pandis, S. N.: General overview: European Integrated project on Aerosol Cloud Climate and Air Quality interactions (EUCAARI) - integrating aerosol research from nano to global scales, Atmos. Chem. Phys., 11, 13061-13143, doi:10.5194/acp11-13061-2011, 2011.

Lewis, S. L., Brando, P. M., Phillips, O. L., van der Heijden, G. M. F. and Nepstad, D.: The 2010 Amazon drought, Science, New York, NY, 331, 6017, doi:10.1126/science.1200807, 2011.

Loeb, N. G. and Su, W.: Direct Aerosol Radiative Forcing Uncertainty Based on a Radiative Perturbation Analysis, J. Climate, 23, 5288-5293, doi:10.1175/2010JCLI3543.1, 2010.

Ma, N., Zhao, C. S., Nowak, A., Müller, T., Pfeifer, S., Cheng, Y. F., Deng, Z. Z., Liu, P. F., Xu, W. Y., Ran, L., Yan, P., Göbel, T., Hallbauer, E., Mildenberger, K., Henning, S., Yu, J., Chen, L. L., Zhou, X. J., Stratmann, F., and Wiedensohler, A.: Aerosol optical properties in the North China Plain during HaChi campaign: an in-situ optical closure study, Atmos. Chem. Phys., 11, 5959-5973, doi:10.5194/acp-11-5959-2011, 2011.

Ma, N., Zhao, C. S., Müller, T., Cheng, Y. F., Liu, P. F., Deng, Z. Z., Xu, W. Y., Ran, L., Nekat, B., van Pinxteren, D., Gnauk, T., Müller, K., Herrmann, H., Yan, P., Zhou, X. J., and Wiedensohler, A.: A new method to determine the mixing state of light absorbing carbonaceous using the measured aerosol optical properties and number size distributions, Atmos. Chem. Phys., 12, 23812397, doi:10.5194/acp-12-2381-2012, 2012.

Mack, L. A., Levin, E. J. T., Kreidenweis, S. M., Obrist, D., Moosmüller, H., Lewis, K. A., Arnott, W. P., McMeeking, G. R., Sullivan, A. P., Wold, C. E., Hao, W.-M., Collett Jr., J. L., and Malm, W. C.: Optical closure experiments for biomass smoke aerosols, Atmos. Chem. Phys., 10, 9017-9026, doi:10.5194/acp10-9017-2010, 2010.

Magi, B. I., Hobbs, P. V, Schmid, B. and Redemann, J.: Vertical profiles of light scattering, light absorption, and single scattering albedo during the dry, biomass burning season in southern Africa and comparisons of in situ and remote sensing measurements of aerosol optical depths, J. Geophys. Res., 108, 8504, doi:10.1029/2002JD002361, 2003.

Martin, S. T., Andreae, M. O., Althausen, D., Artaxo, P., Baars, H., Borrmann, S., Chen, Q., Farmer, D. K., Guenther, A., Gunthe, S. S., Jimenez, J. L., Karl, T., Longo, K., Manzi, A., Müller, T., Pauliquevis, T., Petters, M. D., Prenni, A. J., Pöschl, U., Rizzo, L. V., Schneider, J., Smith, J. N., Swietlicki, E., Tota, J., Wang, J., Wiedensohler, A., and Zorn, S. R.: An overview of the Amazonian Aerosol Characterization Experiment 2008 (AMAZE08), Atmos. Chem. Phys., 10, 11415-11438, doi:10.5194/acp10-11415-2010, 2010a.

Martin, S. T., Andreae, M. O., Artaxo, P., Baumgardner, D., Chen, Q., Goldstein, A. H., Guenther, A., Heald, C. L., Bracero, O. L. M., McMurry, P. H., Pauliquevis, T., Pöschl, U., Prather, K. 
A., Roberts, G. C., Saleska, S. R., Silva Dias, M. A., Spracklen, D. V., Swietlicki, E. and Trebs, I.: Sources and properties of Amazonian aerosol particles, Rev. Geophys., 48, RG2002, doi:10.1029/2008RG000280, 2010b.

Martins, J. V., Artaxo, P., Liousse, C., Reid, J. S., Hobbs, P. V., and Kaufman, Y. J.: Effects of black carbon content, particle size, and mixing on light absorption by aerosols from biomass burning in Brazil, J. Geophys. Res., 103, 32041-32050, 1998.

Müller, T., Schladitz, A., Massling, A., Kaaden, N., Kandler, K., and Wiedensohler, A.: Spectral absorption coefficients and imaginary parts of refractive indices of Saharan dust during SAMUM-1, Tellus B, 61, 79-95, doi:doi:10.1111/j.1600-0889.2008.00399.x, 2009.

Müller, T., Henzing, J. S., de Leeuw, G., Wiedensohler, A., Alastuey, A., Angelov, H., Bizjak, M., Collaud Coen, M., Engström, J. E., Gruening, C., Hillamo, R., Hoffer, A., Imre, K., Ivanow, P., Jennings, G., Sun, J. Y., Kalivitis, N., Karlsson, H., Komppula, M., Laj, P., Li, S.-M., Lunder, C., Marinoni, A., Martins dos Santos, S., Moerman, M., Nowak, A., Ogren, J. A., Petzold, A., Pichon, J. M., Rodriquez, S., Sharma, S., Sheridan, P. J., Teinilä, K., Tuch, T., Viana, M., Virkkula, A., Weingartner, E., Wilhelm, R., and Wang, Y. Q.: Characterization and intercomparison of aerosol absorption photometers: result of two intercomparison workshops, Atmos. Meas. Tech., 4, 245-268, doi:10.5194/amt-4-245-2011, 2011.

Nessler, R., Weingartner, E., and Baltensperger, U.: Effect of humidity on aerosol light absorption and its implications for extinction and the single scattering albedo illustrated for a site in the lower free troposphere, J. Aerosol Sci., 36, 958-972, doi:10.1016/j.jaerosci.2004.11.012, 2005.

Petzold, A., Schloesser, H., Sheridan, P., Arnott, W. P., Ogren, J., and Virkkula, A.: Evaluation of Multiangle Absorption Photometry for Measuring Aerosol Light Absorption, Aerosol Sci. Technol., 39, 40-51, doi:10.1080/027868290901945, 2005.

Prenni, A. J., Petters, M. D., Kreidenweis, S. M., Heald, C. L., Martin, S. T., Artaxo, P., Garland, R. M., Wollny, A. G., and Pöschl, U.: Relative roles of biogenic emissions and Saharan dust as ice nuclei in the Amazon basin, Nature Geosci., 2, 402-405, doi:10.1038/ngeo517, 2009.

Procopio, A. S., Artaxo, P., Kaufman, Y. J., Remer, L. A., Schafer, J. S., and Holben, B. N.: Multiyear analysis of amazonian biomass burning smoke radiative forcing of climate, Geophys. Res. Lett., 31, L03108, doi:10.1029/2003GL018646, 2004.

Pöschl, U., Martin, S. T., Sinha, B., Chen, Q., Gunthe, S. S., Huffman, J. A., Borrmann, S., Farmer, D. K., Garland, R. M., Helas, G., Jimenez, J. L., King, S. M., Manzi, A., Mikhailov, E., Pauliquevis, T., Petters, M. D., Prenni, A. J., Roldin, P., Rose, D., Schneider, J., Su, H., Zorn, S. R., Artaxo, P., Andreae, M. O.: Rainforest Aerosols as Biogenic Nuclei of Clouds and Precipitation in the Amazon, Science, 329, 1513, doi:10.1126/science.1191056, 2010.

Reid, J. S., Hobbs, V., Ferek, J., Blake, R., and Dunlap, R.: Physical, chemical, and optical properties of regional hazes dominated by smoke in Brazil, J. Geophys. Res., 103, 32059-32080, 1998.

Reid, J. S., Eck, T. F., Christopher, S. A., Koppmann, R., Dubovik, O., Eleuterio, D. P., Holben, B. N., Reid, E. A., and Zhang, J.: A review of biomass burning emissions part III: intensive optical properties of biomass burning particles, Atmos. Chem. Phys., 5, 827-849, doi:10.5194/acp-5-827-2005, 2005.
Rissler, J., Vestin, A., Swietlicki, E., Fisch, G., Zhou, J., Artaxo, P., and Andreae, M. O.: Size distribution and hygroscopic properties of aerosol particles from dry-season biomass burning in Amazonia, Atmos. Chem. Phys., 6, 471-491, doi:10.5194/acp6-471-2006, 2006.

Rizzo, L. V., Artaxo, P., Karl, T., Guenther, A. B., and Greenberg, J.: Aerosol properties, in-canopy gradients, turbulent fluxes and VOC concentrations at a pristine forest site in Amazonia, Atmos. Environ., 44, 503-511, doi:10.1016/j.atmosenv.2009.11.002, 2010.

Rizzo, L. V., Correia, a. L., Artaxo, P., Procópio, a. S., and Andreae, M. O.: Spectral dependence of aerosol light absorption over $\backslash$ newline the Amazon Basin, Atmos. Chem. Phys., 11, 88998912, doi:10.5194/acp-11-8899-2011, 2011.

Rolph, G. D.: Real-time Environmental Applications and Display sYstem (READY) Website, NOAA Air Resources Laboratory, Silver Spring, MD [online] Available from: http://ready.arl.noaa.gov, 2012.

Schafer, J. S., Eck, T. F., Holben, B. N., Artaxo, P., and Duarte, a. F.: Characterization of the optical properties of atmospheric aerosols in Amazônia from long-term AERONET monitoring (1993-1995 and 1999-2006), J. Geophys. Res., 113, 1-16, doi:10.1029/2007JD009319, 2008.

Schkolnik, G., Chand, D., Hoffer, A., Andreae, M., Erlick, C., Swietlicki, E., and Rudich, Y.: Constraining the density and complex refractive index of elemental and organic carbon in biomass burning aerosol using optical and chemical measurements, Atmos. Environ., 41, 1107-1118, doi:10.1016/j.atmosenv.2006.09.035, 2007.

Schuster, G. L., Dubovik, O., and Holben, B. N.: Angstrom exponent and bimodal aerosol size distributions, J. Geophys. Res., 111, 1-14, doi:10.1029/2005JD006328, 2006.

Sena, E. T., Artaxo, P., and Correia, A. L.: Spatial variability of the direct radiative forcing of biomass burning aerosols and the effects of land use change in Amazonia, Atmos. Chem. Phys., 13, 1261-1275, doi:10.5194/acp-13-1261-2013, 2013.

Sheridan, P. J., Jefferson, A., and Ogren, J. A.: Spatial variability of submicrometer aerosol radiative properties over the Indian Ocean during INDOEX, J. Geophys. Res., 107, 8011, doi:10.1029/2000JD000166, 2002.

Shindell, D. and Faluvegi, G.: Climate response to regional radiative forcing during the twentieth century, Nature Geosci., 2, 294-300, doi:10.1038/ngeo473, 2009.

Tuch, T. M., Haudek, A., Müller, T., Nowak, A., Wex, H., and Wiedensohler, A.: Design and performance of an automatic regenerating adsorption aerosol dryer for continuous operation at monitoring sites, Atmos. Meas. Tech., 2, 417-422, doi:10.5194/amt-2-417-2009, 2009.

Virkkula, a., Backman, J., Aalto, P. P., Hulkkonen, M., Riuttanen, L., Nieminen, T., dal Maso, M., Sogacheva, L., de Leeuw, G., and Kulmala, M.: Seasonal cycle, size dependencies, and source analyses of aerosol optical properties at the SMEAR II measurement station in Hyytiälä, Finland, Atmos. Chem. Phys., 11, 4445-4468, doi:10.5194/acp-11-4445-2011, 2011.

Wagner, R., Kandler, K., Linke, C., Muller, T., and Schnaiter, M.: Shape dependency of the extinction and absorption cross sections of dust aerosols modeled as randomly oriented spheroids, AAPP, Atti della Accademia Peloritana dei Pericolanti, Classe di Scienze Fisiche, Matematiche e Naturali, 89, 
1-4, doi:10.1478/C1V89S1P094, 2011.

Wiedensohler, A., Birmili, W., Nowak, A., Sonntag, A., Weinhold, K., Merkel, M., Wehner, B., Tuch, T., Pfeifer, S., Fiebig, M., Fjäraa, A. M., Asmi, E., Sellegri, K., Depuy, R., Venzac, H., Villani, P., Laj, P., Aalto, P., Ogren, J. A., Swietlicki, E., Williams, P., Roldin, P., Quincey, P., Hüglin, C., Fierz-Schmidhauser, R., Gysel, M., Weingartner, E., Riccobono, F., Santos, S., Grüning, C., Faloon, K., Beddows, D., Harrison, R., Monahan, C., Jennings, S. G., O’Dowd, C. D., Marinoni, A., Horn, H.-G., Keck, L., Jiang, J., Scheckman, J., McMurry, P. H., Deng, Z., Zhao, C. S., Moerman, M., Henzing, B., de Leeuw, G., Löschau, G., and Bastian, S.: Mobility particle size spectrometers: harmonization of technical standards and data structure to facilitate high quality long-term observations of atmospheric particle number size distributions, Atmos. Meas. Tech., 5, 657-685, doi:10.5194/amt5-657-2012, 2012.
Zhou, J., Swietlicki, E., Hansson, H. C., and Artaxo, P.: Submicrometer aerosol particle size distribution and hygroscopic growth measured in the Amazon rain forest during the wet season, J. Geophys. Res., 107, 8055, doi:10.1029/2000JD000203, 2002. 